\title{
28. THERMAL EVOLUTION OF SEDIMENTS FROM LEG 139, MIDDLE VALLEY, JUAN DE FUCA RIDGE: AN ORGANIC PETROLOGICAL STUDY ${ }^{1}$
}

\author{
Shaozhi Mao, ${ }^{2}$ Lorraine Buxton Eglinton, ${ }^{3}$ Jean Whelan, ${ }^{3}$ and Li Liu ${ }^{2}$
}

\begin{abstract}
This study is a petrographic examination of the thermal evolution of organic material in sediments from Ocean Drilling Program Leg 139, Middle Valley, Juan de Fuca Ridge. Thermal Alteration Indices (TAI), vitrinite reflectance (\%VR ond $_{\mathrm{o}}$ ande fluorescence color (SFC) are used to provide thermal maturation data from four distinct hydrologic environments in this sedimented rift system. Extremely sharp increases in thermal maturity at Sites 856 and 858 characterize past and present hydrothermally active systems, respectively. Site 857 also shows accelerated maturation but may differ from Site 856 and 858 in that lateral fluid flow may be involved. Site $855 \mathrm{~A}$ is presently immature and gives a good indication of the regional background thermal maturity. A paleotemperature correlation between TAI and other maturity and thermal indicators has been attempted in conjunction with laboratory experiments.
\end{abstract}

\section{INTRODUCTION}

Four distinct hydrologic environments were drilled during Leg 139 of the Ocean Drilling Program (ODP) at Sites 855, 856, 857, and 858. These sites are located in Middle Valley, a sedimented rift valley at the northern part of the Juan De Fuca Ridge (Fig. 1). The four holes drilled at Site 855 penetrated a zone of fluid recharge along the normal fault scarp that bounds the valley to the east. Drilling at Site 856 encountered a large polymetallic sulfide deposit created by past hydrothermal fluid discharge. Holes at Site 857 were drilled into a hydrothermal reservoir zone where high-temperature fluids were suspected to reside in the upper igneous crust beneath a complete sediment blanket. Site 858 is located over an active hydrothermal vent field; several of the holes drilled here penetrated a zone of upflowing hydrothermal fluids.

This paper uses an integrated optical petrologic approach to assess the thermal evolution of organic material in these Middle Valley sediments. Transmitted light kerogen microscopy, in conjunction with incident white light and fluorescent light microscopy are used to determine pollen and spore thermal alteration indices (TAI), vitrinite reflectance $\left(\% \mathrm{VR}_{\mathrm{o}}\right)$ and spore fluorescence color (SFC) as thermal maturity indicators for this study area.

Since the publication of Staplin's TAI scale in 1969, researchers have monitored the color of acid-resistant organic material such as spores and pollen (palynomorphs) as it undergoes progressive and irreversible change in response to increasing temperatures. This index, on a 1-4 scale, is one of many scales currently used by palynologists and organic petrologists. The technique has been valuable to petroleum exploration as a quick and inexpensive means of assessing the thermal maturity of sedimentary rocks. TAI is based on visibly recognizable transformations in the exine or outer structural layer of the pollen grain. The exine is a complex material that includes sporopollenin, a highly resistant "biopolymer" comprised mostly of hydrogen $(\mathrm{H})$, carbon $(\mathrm{C})$, and oxygen $(\mathrm{O})$. Sporopollenin is capable of producing liquid hydrocarbons and gas under catagenesis at different geotemperatures and pressures, with loss of $\mathrm{H}$ and $\mathrm{O}$ and consequent enrichment of $\mathrm{C}$ with condensation and aromatization of the macromolecular structure

\footnotetext{
${ }^{1}$ Mottl, M.J., Davis, E.E., Fisher, A.T., and Slack, J.F. (Eds.), 1994. Proc. ODP, Sci. Results, 139: College Station, TX (Ocean Drilling Program).

${ }^{2}$ Department of Geology, Florida State University, Tallahassee, FL 32306-3026, U.S.A.

${ }^{3}$ Department of Marine Chemistry and Geochemistry, Woods Hole Oceanographic Institution, Woods Hole, MA 02543, U.S.A.
}

(Traverse, 1988). These chemical transformations are manifested optically as a color change in fossil palynomorphs ranging from yellowishgreen for immature rocks, through yellow and orange for more mature rocks, to various shades of brown for overmature rocks, eventually becoming black and opaque, and unidentifiable at high thermal maturities (Fig. 2; Plates 1-3).

Coal petrological techniques also have been applied to the study of dispersed organic particles in sediments (Jacob, 1961, 1967; Alpern, 1970 ) and vitrinite reflectance has become the most widely used maturation parameter in the exploration for oil and gas (Hunt, 1979; Tissot et al., 1987). Vitrinite reflectance also has been successfully applied to areas of geothermal activity to assess the maximum thermal maturation of organic particles in the sediments (Barker et al., 1986; Barker, 1991). Bostick and Pawlewicz (1984) and Ujiié (1986) have demonstrated the sensitivity of vitrinite to thermal changes near igneous intrusions and have shown how this approach can document the sphere of thermal alteration around these intrusive bodies.

Spore fluorescence color (SFC) is a simple, qualitative technique used to provide additional maturity information to support vitrinite reflectance maturity determinations. It is based on the principle that certain molecules produce spectra that move from low to high wavelengths with increasing maturity, when excited by UV- or blue-light irradiation. This technique provides supplementary maturity information and is especially useful in samples containing limited quantities of indigenous vitrinite particles. Figure 3 shows the relationship of vitrinite reflectance to SFC.

\section{METHODS AND MATERIALS}

One hundred and seventy samples from 11 holes drilled during Leg 139 were processed for TAI analysis using conventional palynological laboratory techniques. Samples were collected during the cruise with a sampling frequency of at least one sample per subcore unit, unless the recovery of the core unit was low. The lithology of the studied samples includes unconsolidated, semi-indurated and fully indurated clay (stone), silt(stone), and fine sand(stone). After $\mathrm{HCl}$ and $\mathrm{HF}$ acidification, the residues were sifted through a $20-\mu \mathrm{m}$ sieve. Only the $>20-\mu \mathrm{m}$ fractions were analyzed for TAI.

Thermal alteration indices are most reliable when determined from a single taxa of pollen grain or spore within a sequence. This precludes inaccuracies caused by color differences among different types of pollen grains. It has been shown that gymnosperm, bisaccate, or deltoid pollens are among the most reliable and sensitive to temperature change (J. Jansonius, pers. comm., 1991). We therefore used pine 


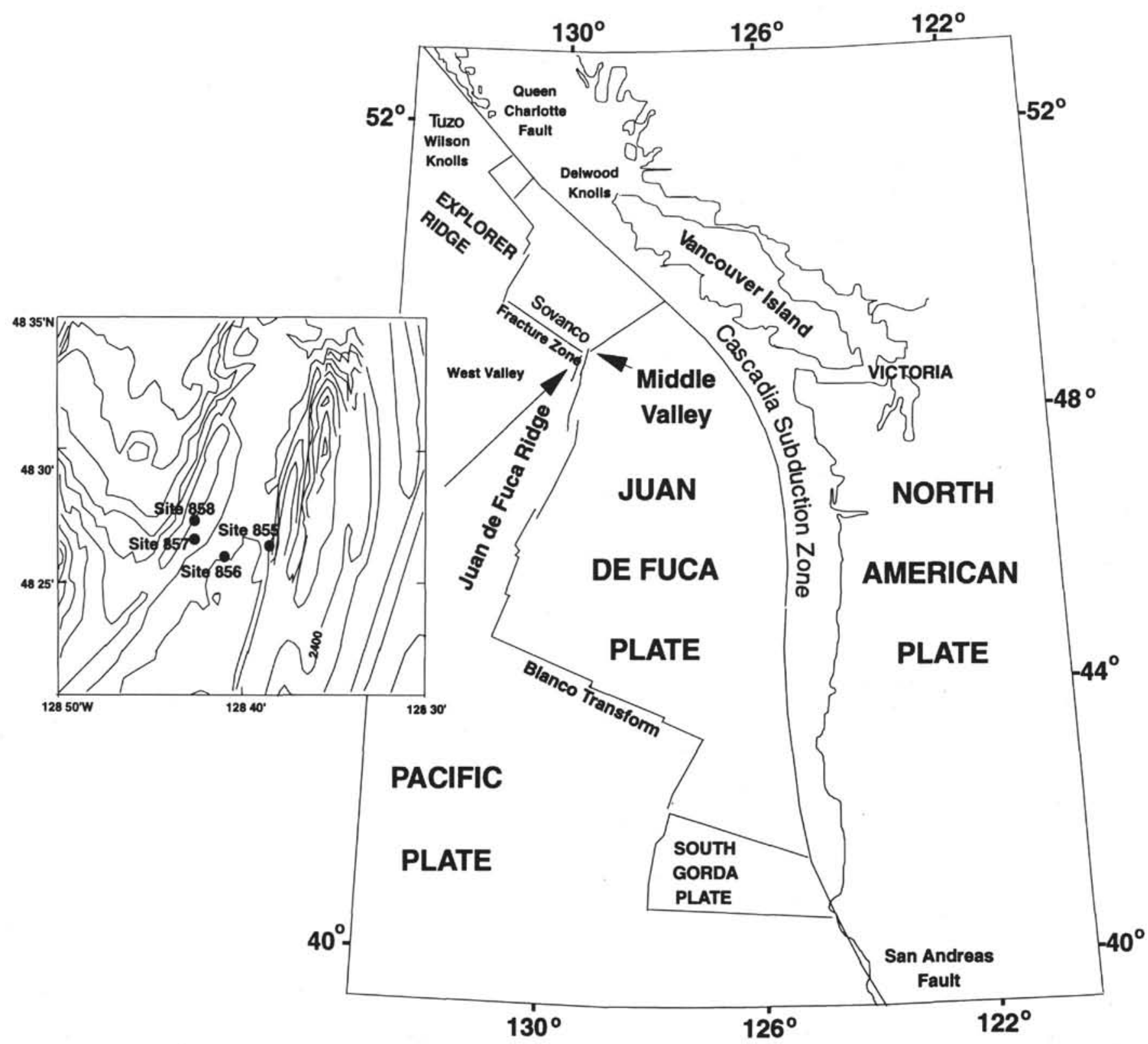

Figure 1. Bathymetry of the northern Juan de Fuca Ridge, shown as contours drawn at 20-m intervals. Site locations for Leg 139 are indicated. From Davis, Mottl, Fisher, et al. (1992).

pollen when possible; spruce pollen was used occasionally. Extreme care must be taken when selecting the pollen grains used for TAI, especially in fine-grained turbiditic sediments containing an abundance of a recycled organic material, because reworked pollen grains may show an array of colors, making differentiation of the indigenous palynomorphs difficult. Where the presence of reworked grains was identified, pollen grains of the same taxa that show the lightest color were considered to be indigenous. At the same time, the predominant colors of most other indigenous bisaccate pine pollen from the same sample were taken into consideration when assigning a particular TAI maturity for each sample. The Philips Petroleum Company's pollen /spore color "standard" (Pearson, 1990) was employed for this study. Table 1 shows the correlation of this scale with other similar scales and parameters used as thermal maturity indicators.

Eighty samples were selected from four well sites in Middle Valley for thermal maturation determination by vitrinite reflectance and spore fluorescence color. Whole-sediment core samples were dried at room temperature, coarsely ground to a particle size of approximately $2 \mathrm{~mm}$ and cold set in an epoxy resin. The samples were then ground and polished according to standard procedure (International Committee for Coal Petrology, 1963, 1971). All vitrinite reflectance measurements were performed on a Zeiss standard universal research microscope-photometer system. Determinations represent the mean average vitrinite reflectance population $\left(\% \mathrm{VR}_{\mathrm{o}}\right)$ of dispersed, indigenous vitrinite particles (i.e., not those particles deemed as reworked from older sediments). These determinations were made using a $\times 40$ oil immersion objective (ne $=1.518$ at $23^{\circ} \mathrm{C}$ ) at $546 \mathrm{~nm}$ wavelength. The photometer is calibrated for linearity and all measurements are corrected using a series of mineral and glass standards of known reflectance under the analysis conditions. Fluorescence blue-light examination was performed on the same microscope fitted with a 100-watt HBO mercury bulb and an LP520, BP450-490 filter set. 


\section{RESULTS AND DISCUSSION}

\section{Site 855}

Four holes were drilled at Site 855 (A, B, C, D). The holes penetrated the basement basalt at depths ranging from $45 \mathrm{mbsf}(855 \mathrm{~B})$ to $108 \mathrm{mbsf}$ (855D). Based on the observations that sediment porewater at depth has a chemical composition similar to seawater, this site has been interpreted as a possible zone of fluid recharge that follows a pathway along the normal fault scarp that bounds the valley to the east (Davis, Mottl, Fisher, et al., 1992). The overlying sediment is primarily comprised of turbidites with intervening hemipelagic units. Some disruption and mixing of shallower-water-deposited intervals with deeper ones was reported as a result of drilling (Davis, Mottl, Fisher, et al., 1992)

Three holes from this site (Holes $855 \mathrm{~A}, \mathrm{~B}$, and C) were investigated for TAI. All of the pollen grains from the site show low degrees of alteration and TAI reaches values of 1 to 2 (Tables 2, 3; Fig. 2). Based on these TAI values, sediments at these sites are classified as immature. However, more mature orange pine pollen grains are observed in certain intervals in Hole 855A. The most significant alteration of bisaccate conifer pollen grains is found at 74.30 mbsf (Sample 139-855A-8RCC), just above the first penetrated basalt in Hole 855A; at $14 \mathrm{~m}$ above the penetrated basalt in the sample at $31.01 \mathrm{~m}(139-855 \mathrm{~B}-4 \mathrm{R}-5,51-55$ $\mathrm{cm}$ ) at Hole 855B; and at $11 \mathrm{~m}$ above the basalt in the sample at 95.05 $\mathrm{m}(139-855 \mathrm{C}-11 \mathrm{R}-1,42-47 \mathrm{~cm})$ at Hole $855 \mathrm{C}$. The fluctuations in TAI, particularly in Hole $855 \mathrm{~A}$, could be the result of heating from a

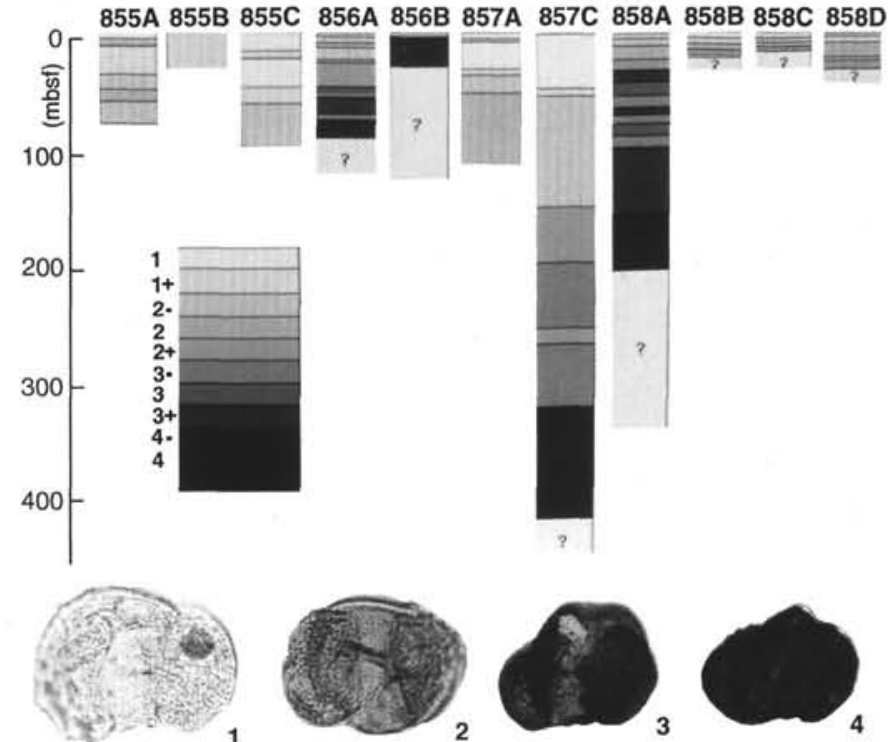

Figure 2. Vertical distribution pattern of TAI from Leg 139 Sites studied. 1. TAI 1, Sample 139-855C-1R-2, 94-96 cm. 2. TAI 2, Sample 139-857A-1H-6, 30-32 cm. 3. TAI 3, Sample 139-858A-12X-1, 10-12. 4. TAI 4, Sample 139-856A-9H-9, 142-146 cm. See Table 1 for the designated pollen color of each TAI rank and suggested paleotemperature.

Table 13. Comparison of different schemes of TAI standards and suggested paleotemperatures for this study.

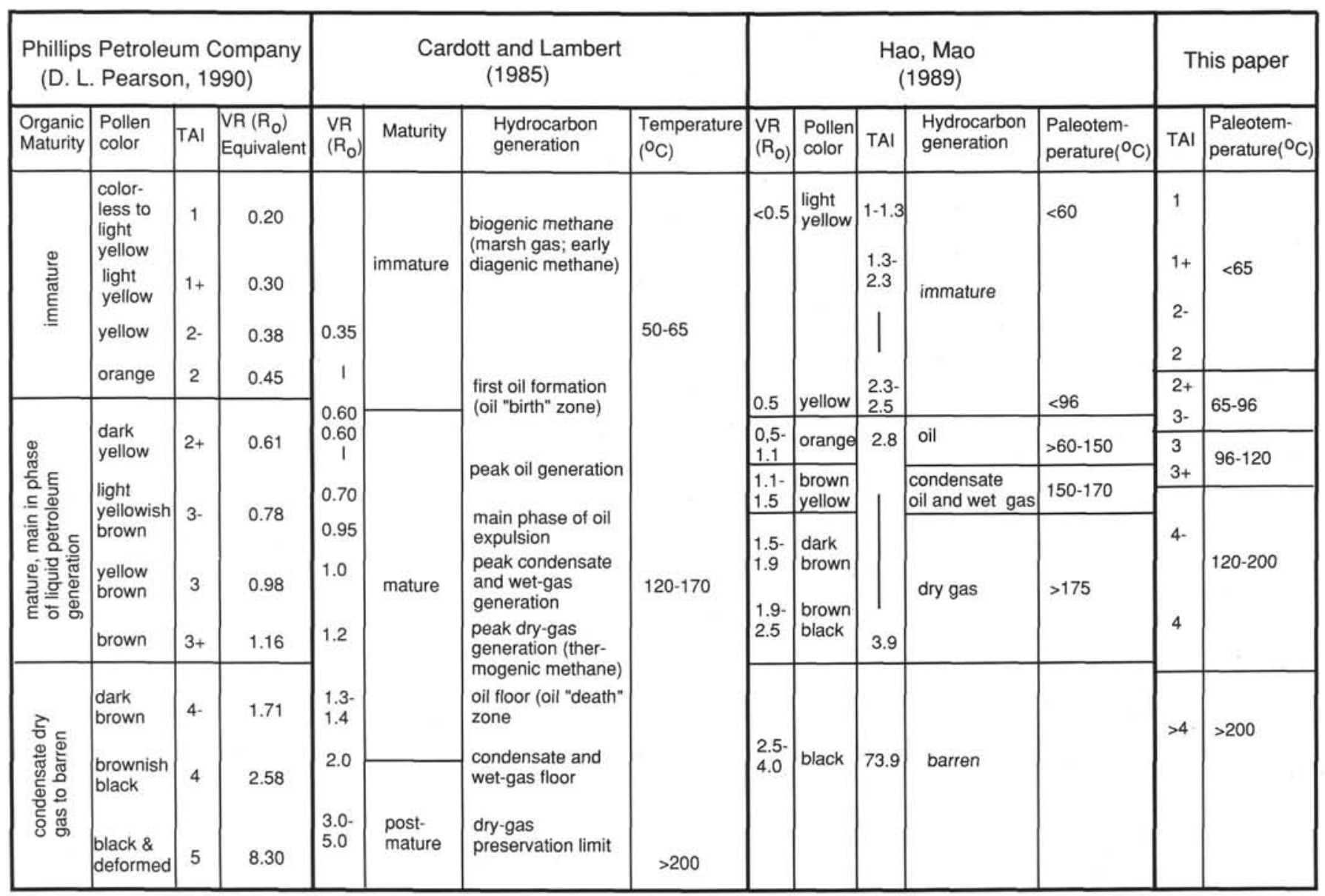


Figure 3. Relationship between vitrinite reflectance $\left(\% \mathrm{VR}_{\mathrm{o}}\right)$ and spore fluorescence color (SFC).

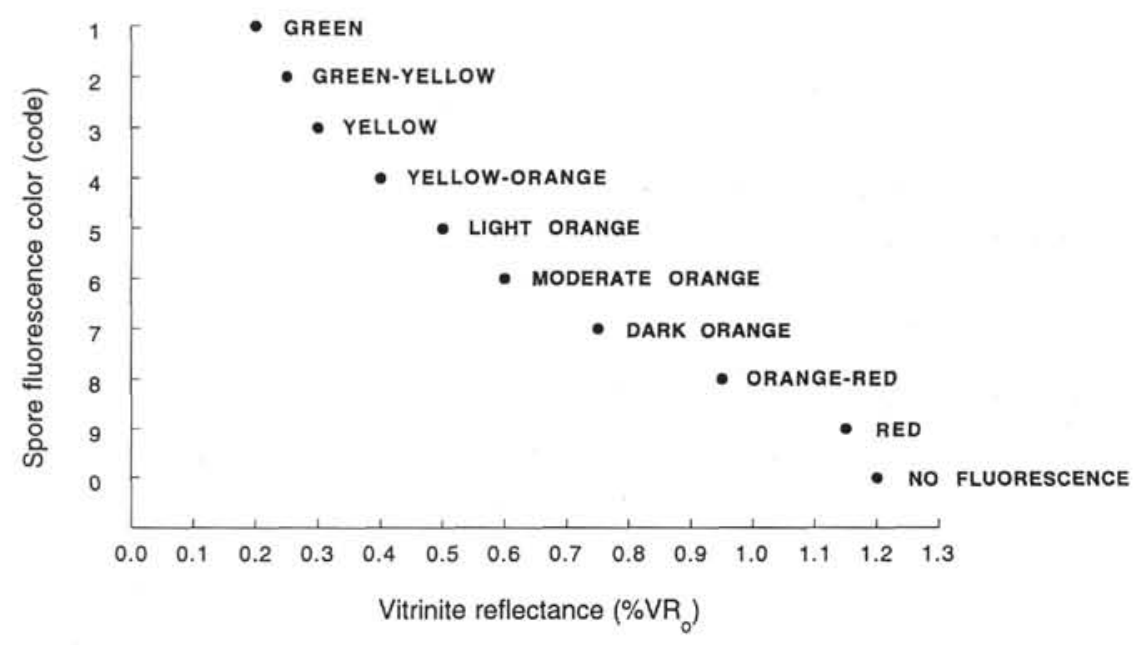

Table 3. TAI of Hole 855C.

\begin{tabular}{|c|c|c|c|c|}
\hline $\begin{array}{l}\text { Core, section, } \\
\text { interval }(\mathrm{cm})\end{array}$ & $\begin{array}{l}\text { Depth } \\
\text { (mbsf) }\end{array}$ & TAI & $\begin{array}{c}\mathrm{R}_{\mathrm{o}} \\
\text { equivalent }\end{array}$ & $\begin{array}{l}\text { Paleotemperature } \\
\left({ }^{\circ} \mathrm{C}\right) \text { inferred }\end{array}$ \\
\hline \multicolumn{5}{|l|}{ 139-855C- } \\
\hline IR-2, 94-96 & 2.44 & 1 & 0.20 & $<65$ \\
\hline $2 R-4,33-37$ & 13.53 & 1 & 0.20 & $<65$ \\
\hline 2R-6, 84-88 & 17.04 & $1+$ & 0.30 & $<65$ \\
\hline $3 R-3,97-99$ & 21.67 & $1+$ & 0.30 & $<65$ \\
\hline $4 \mathrm{R}-1,42-44$ & 27.52 & 1 & 0.20 & $<65$ \\
\hline $5 \mathrm{R}-\mathrm{CC}$ & 46.50 & 1 & 0.20 & $<65$ \\
\hline $6 \mathrm{R}-7,3-7$ & 55.28 & $1+$ & 0.30 & $<65$ \\
\hline $7 R-1,94-98$ & 57.04 & $1+$ & 0.30 & $<65$ \\
\hline $7 R-3,107-111$ & 60.17 & $1+$ & 0.30 & $<65$ \\
\hline $8 \mathrm{R} 1-1,35-39$ & 66.05 & $2-$ & 0.38 & $<65$ \\
\hline $9 \mathrm{R}-1,44-48$ & 75.64 & $2-$ & 0.38 & $<65$ \\
\hline $10 \mathrm{R}-5,7-11$ & 89.47 & $2-$ & 0.38 & $<65$ \\
\hline $11 \mathrm{R}-1,42-47$ & 95.02 & $2-$ & 0.38 & $<65$ \\
\hline
\end{tabular}

is also immature; reflectance values range from $0.32 \% \mathrm{VR}_{\mathrm{o}}$ at 6.64 mbsf (139-855B-2R-1, 94-98 cm) to $0.31 \% \mathrm{VR}_{\mathrm{o}}$ at $31.34 \mathrm{mbsf}$ (139$855 \mathrm{~B}-5 \mathrm{R}-1,34-40 \mathrm{~cm}$ ) with a maximum at $28.01 \mathrm{mbsf}$ of $0.38 \% \mathrm{VR}_{\mathrm{o}}$ $(139-855 \mathrm{~B}-4 \mathrm{R}-3,51-55 \mathrm{~cm})$. Hole $855 \mathrm{C}$ shows a slight increase in thermal maturity relative to $855 \mathrm{~A}$ and $855 \mathrm{~B}$ and indicates an immature thermal maturity, approaching marginal maturity. $\mathrm{VR}_{\mathrm{o}}$ data down Hole $855 \mathrm{C}$ range from $0.38 \% \mathrm{VR}_{\mathrm{o}}$ at $2.44 \mathrm{mbsf}(139-855 \mathrm{C}-1 \mathrm{R}-2$, $94-96 \mathrm{~cm})$ to $0.43 \% \mathrm{VR}_{\mathrm{o}}$ at $95.02 \mathrm{mbsf}(139-855 \mathrm{C}-11-1,42-47 \mathrm{~cm})$ with an increase to $\sim 0.45 \% \mathrm{VR}_{\mathrm{o}}$ between 21.67 and $55.53 \mathrm{mbsf}$ (139-855C-3R-3, 97-99 cm, and 855C-6R-7, 3-7 cm).

SFC observations of Hole $855 \mathrm{~A}$ (Table 3 ) indicate the presence of a probable recycled spore population as interpreted from a light-orange to orange $\left(=\sim 0.5-0.6 \% \mathrm{VR}_{\mathrm{o}}\right)$ spore florescence color, particularly at $0.91 \mathrm{mbsf}(139-855 \mathrm{~A}-1 \mathrm{R}-1,91-94 \mathrm{~cm})$. This low-level reworking may account for the slight increases observed in TAI down this hole, although we cannot preclude the possibility that sediments were mixed during drilling, as reported by Davis, Mottl, Fisher, et al. (1992). However, samples between 2.44 and $55.53 \mathrm{mbsf}$ and between 75.14 and $95.02 \mathrm{mbsf}$ in Hole $855 \mathrm{C}$ show a slight increase in matrix hydrocarbon staining, which is consistent with slightly elevated maturities and may be indicative of the evolution of hydrocarbon precursor material.

To summarize, there is good agreement among optical maturity parameters at this site, which confirm the immaturity of the sediments, equivalent in general to a range $0.30 \%$ to $0.40 \% \mathrm{VR}_{\mathrm{o}}$. Inferred paleotemperatures based on data published in Hao and Mao (1989) and Cardott and Lambert (1985), indicate a maximum exposure temperature of $<65^{\circ} \mathrm{C}$ (Tables 1 and 2); however, vitrinite reflectance data suggest a temperature of $<50^{\circ} \mathrm{C}$, below oil window maturity (Hunt, 1979). The thermal maturity data collected from this site can be considered as a representative regional background determination. 
Table 4. Vitrinite reflectance and spore fluorescence color for whole sediment samples from Holes $855 \mathrm{~A}, \mathbf{8 5 5 B}$, and $855 \mathrm{C}$.

\begin{tabular}{|c|c|c|c|c|c|}
\hline $\begin{array}{l}\text { Core, section, } \\
\text { interval }(\mathrm{cm})\end{array}$ & $\begin{array}{l}\text { Depth } \\
\text { (mbsf) }\end{array}$ & $\begin{array}{l}\text { Vitrinite } \\
\text { reflectance } \\
\left(\% \mathrm{VR}_{\mathrm{o}}\right)^{\mathrm{a}}\end{array}$ & $\begin{array}{c}\text { Number of } \\
\text { readings }\end{array}$ & $\begin{array}{l}\text { Standard } \\
\text { deviation }\end{array}$ & $\begin{array}{l}\text { Spore fluorescence } \\
\text { color (SFC) }\end{array}$ \\
\hline \multicolumn{6}{|l|}{$139-855 \mathrm{~A}-$} \\
\hline $1 \mathrm{R}-1,91-94$ & 0.91 & 0.37 & 8 & 0.03 & yellow \\
\hline $2 R-4,100-102$ & 13.10 & 0.38 & 4 & 0.02 & yellow-orange \\
\hline $3 R-2,19-21$ & 18.29 & 0.42 & 13 & 0.04 & yellow-orange \\
\hline $4 \mathrm{R}-1,19-21$ & 26.19 & 0.43 & 5 & 0.02 & yellow \\
\hline $5 R-1,13-15$ & 35.63 & 0.42 & 6 & 0.03 & yellow-orange \\
\hline $6 \mathrm{R}-1,91-94$ & 46.41 & 0.44 & 6 & 0.03 & yellow \\
\hline $7 R-1,92-96$ & 56.02 & 0.43 & 1 & 0.00 & yellow-orange \\
\hline \multicolumn{6}{|l|}{$139-855 \mathrm{~B}-$} \\
\hline $2 \mathrm{R}-1,94-98$ & 6.64 & 0.32 & 8 & 0.05 & yellow \\
\hline $4 \mathrm{R}-1,51-55$ & 25.01 & 0.34 & 5 & 0.03 & yellow/yellow-orange \\
\hline $4 \mathrm{R}-3,51-55$ & 28.01 & 0.38 & 12 & 0.09 & yellow \\
\hline $5 R-1.34-40$ & 34.34 & 0.31 & 8 & 0.06 & yellow \\
\hline \multicolumn{6}{|l|}{$139-855 \mathrm{C}$ - } \\
\hline $1 R-2,94-96$ & 2.44 & 0.38 & 4 & 0.01 & yellow-orange \\
\hline $3 R-3,97-99$ & 21.67 & 0.46 & 9 & 0.04 & yellow-orange \\
\hline $6 R-7,3-7$ & 55.28 & 0.45 & 3 & 0.01 & yellow-orange \\
\hline $8 \mathrm{R}-1,35-39$ & 66.05 & 0.36 & 3 & 0.06 & yellow/yellow-orange \\
\hline $9 \mathrm{R}-1,44-48$ & 75.64 & 0.41 & 3 & 0.02 & yellow-orange/light orange \\
\hline $11-1,42-47$ & 95.02 & 0.43 & 7 & 0.03 & yellow-orange \\
\hline
\end{tabular}

${ }^{2}$ Mean vitrinite reflectance percent in oil $\left(\mathrm{n}_{\mathrm{e}} 1.518\right.$ at $\left.23^{\circ} \mathrm{C}\right)$.

\section{Site 856}

Eight holes were drilled at this site, but only two holes were sampled for this study (856A, 856B). The site is situated over a small ( 800 -m wide) uplifted mound that was once hydrothermally active. The sediments predominantly include turbidites, coarse clastic layers of massive sulfides interbedded with silt, to fine sand turbidites and massive sulfides.

The TAI data for the two holes are markedly different and indicate that the holes have been affected by different degrees of heating. The pollen color changes quite rapidly with increasing depth, from light yellow at the top of the holes to brown-black in samples at 86.42 mbsf (139-856A-11X-1, 22-26 cm) and $36.04 \mathrm{mbsf}(139-856 \mathrm{~B}-5 \mathrm{H}-$ 4, 124-128 cm). (Tables 5, 6; Fig. 2). Hole 856A shows a sharp but gradual change in pollen color while Hole $856 \mathrm{~B}$ exhibits a dramatic, rapid color change over the top 10 -m interval. The fossil pollen grains are consistently absent from samples below Core 139-856B-9H ( 62 mbsf), and only black carbonized fragments were encountered in these samples.

The organic content of the shales and mudstones in Hole 856A ranges from lean to moderate. Inertinite clasts constitute up to $70 \%$ of the terrestrially derived organic assemblage with vitrinite ranging from $5 \%$ to $30 \%$ of the total organic abundance. The vitrinite particles are fine- to medium-grained $(5 \mu \mathrm{m}-20 \mu \mathrm{m})$. Organic bitumen staining of the matrix, often indicative of generated or migrated liquid hydrocarbons, remains trace to low throughout the hole, except in mudstones at $24.95 \mathrm{mbsf}(139-856 \mathrm{~A}-4 \mathrm{H}-3,25-29 \mathrm{~cm})$ and $70.22 \mathrm{mbsf}(139-856 \mathrm{~A}-$ $9 \mathrm{H}-1,102-146 \mathrm{~cm})$ where moderate staining was observed.

A stepped increase in vitrinite reflectance with depth is observed in Hole 856A. This is indicative of strong thermal perturbations (Fig. 5; Table 7). Percent $\mathrm{VR}_{\mathrm{o}}$ dramatically increases from an immature $0.33 \% \mathrm{VR}_{\mathrm{o}}$ at $2.19 \mathrm{mbsf}(139-856 \mathrm{~A}-1 \mathrm{H}-2,69-72 \mathrm{~cm})$ to an oil window maturity of $0.78 \% \mathrm{VR}_{\mathrm{o}}$ by $24.95 \mathrm{mbsf}$ (139-856A-4H-3, 25-29 $\mathrm{cm}$ ) and remains fairly linear except for the lower measurement of $0.71 \%$ from Sample $139-856 \mathrm{~A}-7 \mathrm{H}-2,18-22 \mathrm{~cm}$ at $51.88 \mathrm{mbsf}$, which may be neglected because of its single measurement. There is a subsequent increase to $0.97 \% \mathrm{VR}_{0}$ as thermal maturity approaches the end of the oil window at $65.45 \mathrm{mbsf}(139-856 \mathrm{~A}-8 \mathrm{H}-4,125-127 \mathrm{~cm})$ and continues to rise to a maximum of $2.11 \% \mathrm{VR}_{\mathrm{o}}$ (dry gas maturity) by 105.94 mbsf (139-856A-13X-1, 64-67 cm). SFC observations, however, record a more gradual but still rapid increase in maturity from yellow at $2.19 \mathrm{mbsf}(139-856 \mathrm{~A}-1 \mathrm{H}-2,69-72 \mathrm{~cm})$ through lightorange at $18.94 \mathrm{mbsf}(139-856 \mathrm{~A}-3 \mathrm{H}-5,74-78 \mathrm{~cm})$, jumping to dark$\mathrm{red} /$ brown by $33.46 \mathrm{mbsf}(139-856 \mathrm{~A}-5 \mathrm{H}-4,38-42 \mathrm{~cm})$. These data indicate that the sediments have been subjected to elevated temperatures and possibly to circulating hydrothermal fluids.

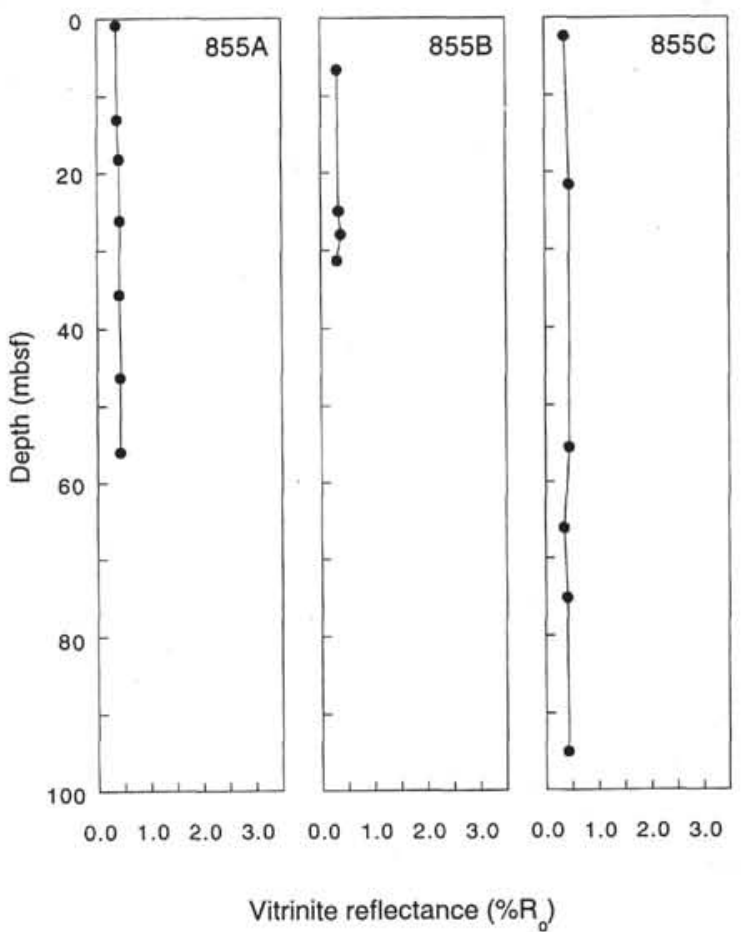

Figure 4. Vitrinite reflectance maturation profiles for Holes $855 \mathrm{~A}, 855 \mathrm{~B}$, and $855 \mathrm{C}$.

Hole 856B contains an assemblage of predominantly terrigenous organic matter with minor amounts of liptinitic material present in the form of dinoflagellates, spores, and pollen grains. Thermal maturity of Hole $856 \mathrm{~B}$ shows a sharp increase between $0.48 \mathrm{mbsf}(139-856 \mathrm{~B}-1 \mathrm{H}-$ $1,48-52 \mathrm{~cm})$ and $10.66 \mathrm{mbsf}(139-856 \mathrm{~B}-2 \mathrm{H}-6,136-140 \mathrm{~cm})$. The shallowest sample, $139-856-1 \mathrm{H}-1$, contains a low to moderate abundance of organic particles that are dominated by inertinite clasts. However, only two good-quality, indigenous vitrinite particles are present. There is a high abundance of immature, liptinite streaks and a moderate and evenly distributed light brown hydrocarbon staining of the sediment matrix. SFC observations show a wide range of spore fluorescence, indicating the presence of reworked material. By $10.66 \mathrm{mbsf}$ and 12.21 mbsf $(139-856 \mathrm{~B}-3 \mathrm{H}-1,91-95 \mathrm{~cm})$ it becomes increasingly difficult to differentiate between indigenous vitrinite, low-level reworked vitrinites, and fusinitic material. The liptinite streaks within the groundmass are black, indicating that they have thermally matured. The mineral groundmass is more flasery in nature (jumbled), rich in what are thought to be calc-aluminum silicates and illite; it exhibits a green stain, suggesting the presence of chlorite. Taken together, these observations indicate a temperature in the range of or exceeding $250^{\circ} \mathrm{C}$ (Barker, 1991; Stach et al., 1982). At 36.04 mbsf (139-856B-5H-4, $124-128 \mathrm{~cm}$ ) a moderately strong $\mathrm{Fe}$-oxide staining of the mineral groundmass is observed, perhaps indicating that circulating oxidizing fluids have been channeled through these sediments. The sample at $62.90 \mathrm{mbsf}(139-856 \mathrm{~B}-9 \mathrm{X}-1,60-64 \mathrm{~cm})$ is particularly interesting due to the presence of black carbonaceous specks, possibly analogous to the black carbonaceous soot previously reported (Davis, Mottl, Fisher, et al., 1992). Also, faint black outlines ("ghost clasts") were observed, possibly representing outlines or relics of volatile, liptinitic particles that were originally present at lower temperatures. A high abundance of euhedral pyrite is associated with the matrix at this depth. These compositions and textures persist to the base of the analyzed section 101.98 mbsf (139-856B-14X-1, 118-121 cm).

The first sharp increase in reflectance values in Hole $856 \mathrm{~B}$ is coincident with a slumped clastic sulfide deposit (Davis, Mottl, Fisher, et al., 1992), which was probably exposed to higher hydrothermal temperatures prior to slumping. $\mathrm{VR}_{\mathrm{o}}$ increases from a marginally mature 
Table 5. TAI of Hole 856A.

\begin{tabular}{lrccc}
\hline $\begin{array}{c}\text { Core, section, } \\
\text { interval }(\mathrm{cm})\end{array}$ & $\begin{array}{c}\text { Depth } \\
\text { (mbsf) }\end{array}$ & TAI & $\begin{array}{c}\mathrm{R}_{\mathrm{o}} \\
\text { equivalent }\end{array}$ & $\begin{array}{c}\text { Paleotemperature } \\
\left({ }^{\circ} \mathrm{C}\right) \text { inferred }\end{array}$ \\
\hline 139-856A- & & & & \\
$1 \mathrm{H}-2,69-72$ & 2.19 & $1+$ & 0.30 & $<65$ \\
$2 \mathrm{H}-4,65-67$ & 7.85 & $2-$ & 0.38 & $<65$ \\
$2 \mathrm{H}-5,39-41$ & 9.09 & 2 & 0.45 & $<65$ \\
$3 \mathrm{H}-5,74-78$ & 18.94 & 2 & 0.45 & $<65$ \\
$3 \mathrm{H}-7,34-38$ & 21.54 & 2 & 0.45 & $<65$ \\
$4 \mathrm{H}-3,25-29$ & 24.95 & $2+$ & 0.61 & $65-96$ \\
$5 \mathrm{H}-3,38-42$ & 33.46 & 3 & 0.98 & $96-120$ \\
$6 \mathrm{H}-4,55-59$ & 45.75 & 3 & 0.98 & $96-120$ \\
$7 \mathrm{H}-2,18-22$ & 51.88 & $3-$ & 0.78 & $96-120$ \\
$7 \mathrm{H}-3,30-34$ & 53.50 & $3+$ & 0.98 & $120-200$ \\
$8 \mathrm{H}-4,125-127$ & 65.45 & $3-$ & 0.78 & $96-120$ \\
$9 \mathrm{H}-1,142-146$ & 70.62 & $4-$ & 1.71 & $120-200$ \\
$9 \mathrm{H}-1,32-36$ & 78.52 & 4 & 2.58 & $120-200$ \\
$10 \mathrm{X}-2,90-93$ & 81.10 & 4 & 2.58 & $120-200$ \\
$11 \mathrm{X}-1,22-26$ & 86.42 & 4 & 2.58 & $120-200$ \\
$12 \mathrm{X}-1,40-44$ & 96.10 & $>4(?)$ & $>2.58(?)$ & $>200(?)$ \\
$13 \mathrm{X}-1,64-67$ & 105.94 & $>4(?)$ & $>2.58(?)$ & $>200(?)$ \\
\hline
\end{tabular}

Table 6. TAI of Hole 856B.

\begin{tabular}{lrccc}
\hline $\begin{array}{c}\text { Core, section, } \\
\text { interval }(\mathrm{cm})\end{array}$ & $\begin{array}{c}\text { Depth } \\
(\mathrm{mbs})\end{array}$ & TAI & $\begin{array}{c}\mathrm{R}_{\mathrm{o}} \\
\text { equivalent }\end{array}$ & $\begin{array}{c}\text { Paleotemperature } \\
\left({ }^{\circ} \mathrm{C}\right) \text { inferred }\end{array}$ \\
\hline 139-856B- & & & & \\
$1 \mathrm{H}-1,48-52$ & 0.48 & $1+$ & 0.30 & $<65$ \\
$2 \mathrm{H}-6,136-140$ & 10.66 & 4 & 1.71 & $120-200$ \\
$3 \mathrm{H}-1,91-95$ & 12.21 & 4 & 1.71 & $120-200$ \\
$4 \mathrm{H}-4,112-116$ & 26.42 & 4 & 1.71 & $120-200$ \\
$5 \mathrm{H}-4,124-128$ & 36.04 & 4 & 1.71 & $120-200$ \\
$7 \mathrm{H}-4,4-8$ & 53.84 & $?$ & $?$ & $?$ \\
$7 \mathrm{H}-5,10-14$ & 55.40 & $?$ & $?$ & $?$ \\
$8 \mathrm{H}-1,106-108$ & 59.86 & 4 & 2.58 & $120-200$ \\
$9 \mathrm{X}-1,60-64$ & 62.90 & $>4(?)$ & $>2.58(?)$ & $>200(?)$ \\
$10 \mathrm{H}-2,44-48$ & 72.74 & $>4(?)$ & $>2.58(?)$ & $>200(?)$ \\
$13 \mathrm{X}-1,34-38$ & 91.44 & $>4(?)$ & $>2.58(?)$ & $>200(?)$ \\
$14 \mathrm{X}-1,118-121$ & 101.98 & $>4(?)$ & $>2.58(?)$ & $>200(?)$ \\
\hline
\end{tabular}

Table 7. Vitrinite reflectance and spore fluorescence color for whole sediment samples from Holes $856 \mathrm{~A}$ and $856 \mathrm{~B}$.

\begin{tabular}{|c|c|c|c|c|c|}
\hline $\begin{array}{l}\text { Core, section, } \\
\text { interval }(\mathrm{cm})\end{array}$ & $\begin{array}{l}\text { Depth } \\
\text { (mbsf) }\end{array}$ & $\begin{array}{l}\text { Vitrinite } \\
\text { reflectance } \\
\left(\% R_{\ominus}\right)^{a}\end{array}$ & $\begin{array}{l}\text { Number of } \\
\text { readings }\end{array}$ & $\begin{array}{l}\text { Standand } \\
\text { deviation }\end{array}$ & $\begin{array}{l}\text { Spore fluorescence } \\
\text { color (SFC) }\end{array}$ \\
\hline \multicolumn{6}{|l|}{$139-856 \mathrm{~A}-$} \\
\hline IH-2, 69-72 & 2.19 & 0.33 & 13 & 0.04 & yellow \\
\hline $2 \mathrm{H}-5,39-41$ & 9.09 & 0.37 & 5 & 0.10 & yellow-orange/light orange \\
\hline $3 \mathrm{H}-5,74-78$ & 18.94 & 0.47 & 7 & 0.07 & light orange \\
\hline $4 \mathrm{H}-3,25-29$ & 24.95 & 0.78 & 8 & 0.09 & dark orange/red \\
\hline $5 \mathrm{H}-4,38-42$ & 34.96 & 0.78 & 15 & 0.06 & dark red/brown \\
\hline $6 \mathrm{H}-4,55-59$ & 45.75 & 0.77 & 9 & 0.19 & dark orange ?? \\
\hline $7 \mathrm{H}-2,18-22$ & 51.88 & 0.71 & $\hat{i}$ & 0.00 & mid-orange/dark orange?? \\
\hline $8 \mathrm{H}-4,125-127$ & 65.45 & 0.97 & 12 & 0.08 & none \\
\hline $9 \mathrm{H}-1,142-146$ & 70.62 & 1.32 & 11 & 0.09 & none \\
\hline $10 \times-2,90-93$ & 81.10 & 1.64 & 16 & 0.12 & none \\
\hline iIX $-1,22-26$ & 86.42 & 1.54 & is & 0.09 & none \\
\hline $12 \mathrm{X}-1,40-44$ & 96.10 & 1.71 & 17 & 0.17 & none \\
\hline $13 X-1.64-67$ & 105.94 & 2.11 & 6 & 0.29 & none \\
\hline \multicolumn{6}{|l|}{$139-856 \mathrm{~B}-$} \\
\hline $1 \mathrm{H}-1,48-52$ & 0.48 & 0.46 & 2 & 0.02 & yellow-orange/light orange \\
\hline $2 \mathrm{H}-6,136-140$ & 10.66 & 2.27 & 15 & 0.13 & none \\
\hline $3 \mathrm{H}-1,91-95$ & 12.21 & 2.32 & 18 & 0.17 & none \\
\hline $4 \mathrm{H}-4,112-116$ & 26.42 & 2.04 & 20 & 0.23 & none \\
\hline $5 \mathrm{H}-4,124-128$ & 36.04 & 2.15 & 17 & 0.12 & none \\
\hline $9 X-1,60-64$ & 62.90 & 2.71 & 16 & 0.12 & none \\
\hline $10 \mathrm{H}-2,44-48$ & 72.74 & 2.39 & 17 & 0.18 & none \\
\hline $14 \mathrm{X}-1,118-121$ & 101.98 & 3.35 & 8 & 0.12 & none \\
\hline
\end{tabular}

${ }^{2}$ Mean vitrinite reflectance percent in oil $\left(\mathrm{n}_{\mathrm{e}} 1.518\right.$ at $\left.23^{\circ} \mathrm{C}\right)$.

$0.46 \%$ at $0.48 \mathrm{mbsf}(139-856 \mathrm{~B}-1 \mathrm{H}-1,48-52 \mathrm{~cm})$ to a postmature (zone of dry gas) $2.27 \%$ by 10.66 mbsf (139-856B-2H-6, 136-140 $\mathrm{cm})$. This represents a strong increase in temperatures from $\angle 50^{\circ} \mathrm{C}$ to $>200^{\circ} \mathrm{C}$ (Hunt, 1979). $\mathrm{VR}_{0}$ fluctuates in the $2 \%-2.5 \%$ range between 10.66 and 36.04 mbsf $(139-856 \mathrm{~B}-5 \mathrm{H}-4,124-128 \mathrm{~cm})$. A further significant increase in thermal maturity, to $2.71 \% \mathrm{VR}_{\mathrm{o}}$, occurs at 62.9 mbsf (139- 856B-9X-1, 60-64 cm), followed by an equally significant drop to $2.39 \%$ by $72.74 \mathrm{~m}$ (139-856B-10H-2, $44-48 \mathrm{~cm})$. VR then rises to a maximum recorded value of $3.35 \% \mathrm{VR}_{\mathrm{o}}$ by 101.98

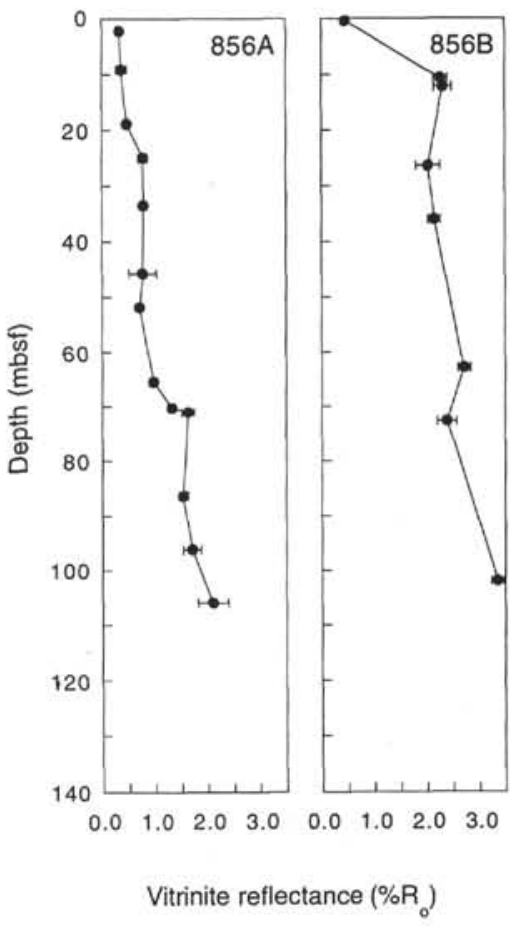

Figure 5. Vitrinite reflectance maturation profiles for Holes 856A and 856B.

mbsf (139-856B-14X-1, 118-121 cm). The sharp inflection in reflectance at $62.9 \mathrm{mbsf}$ is attributed to the thermal alteration of the organic material by a thin basalt sill ( $26 \mathrm{~cm}$ thick) which intrudes at $62.3 \mathrm{mbsf}$. The $V_{R_{0}}$ increase at the base of the hole is consistent with a rise in temperature derived from an underlying basalt that exposed the sediments to temperatures in the range of $300^{\circ} \mathrm{C}$ as interpreted from a vitrinite reflectance value of $\sim 3.35 \% \mathrm{VR}_{\mathrm{o}}$ (Stach et al., 1982).

Hole $856 \mathrm{~B}$ is more mature than Hole $856 \mathrm{~A}$ at all depths, indicating that this hole was proximal to the once-active upflowing hydrothermal fluids, while Hole 856A was distal to the venting fluids. However, overprinting the maturation profile for Hole $856 \mathrm{~B}$ are the subsequent increases in thermal maturity resulting primarily from conductive heating sourced by sill intrusions at $62.3 \mathrm{mbsf}$ and $121 \mathrm{mbsf}$ (139-856B$16 \mathrm{X}-\mathrm{CC}$ ). Two distinct maturation jumps occur in Hole 856A at about $24 \mathrm{mbsf}$ and $65 \mathrm{mbsf}$. Based on the core recovery lithological descriptions (Davis, Mottl, Fisher, et al., 1992), no sills were encountered until about 114 mbsf, making it unlikely that these jumps are directly associated with them. However, the deeper maturation jump ( $65 \mathrm{mbsf}$ ) may correlate to the aureole of alteration caused by a laterally discontinuous sill which intrudes Hole $856 \mathrm{~B}$ at $62 \mathrm{mbsf}$ and may continue towards Hole $856 \mathrm{~A}$. The upper discontinuity of the maturation profile in this hole suggests exposure to higher temperature, probably associated with circulating hydrothermal fluids rather than a sill.

The strong discontinuity in thermal maturity in the upper $10 \mathrm{mbsf}$ of Hole $856 \mathrm{~B}$ supports the presumption that slumping of indurated sulfide deposits has occurred. The organic matter incorporated in these sediments may have been subjected to maturation increases prior to slumping. A phase of sill intrusion is evident, although the timing cannot be constrained by the maturation profiles alone in this case. However, based on the more immature upper sections of Holes $856 \mathrm{~A}$ and $856 \mathrm{~B}$, we suggest that the cessation of hydrothermal activity was followed by the deposition of new turbiditic sediments that were not affected by upflowing hot fluids.

\section{Site 857}

Four holes drilled at this site penetrated a hydrothermal reservoir zone where high-temperature fluids were suspected to reside in the 
Table 8. TAI of Hole 857A.

\begin{tabular}{lrllc}
\hline $\begin{array}{c}\text { Core, section, } \\
\text { interval }(\mathrm{cm})\end{array}$ & $\begin{array}{c}\text { Depth } \\
\text { (mbsf) }\end{array}$ & TAI & $\begin{array}{c}\mathrm{R}_{\circ} \\
\text { equivalent }\end{array}$ & $\begin{array}{c}\text { Paleotemperature } \\
\left({ }^{\circ} \mathrm{C}\right) \text { inferred }\end{array}$ \\
\hline 139-857A- & & & & \\
1H-1, 28-32 & 2.18 & 1 & 0.20 & $<65$ \\
$1 \mathrm{H}-2,30-34$ & 3.70 & 1 & 0.20 & $<65$ \\
1H-3, 29-33 & 5.19 & $1+$ & 0.30 & $<65$ \\
$2 \mathrm{H}-4,61-63$ & 16.51 & 1 & 0.20 & $<65$ \\
$2 \mathrm{H}-6,4-6$ & 18.94 & 1 & 0.20 & $<65$ \\
$4 \mathrm{H}-5,94-98$ & 28.84 & 1 & 0.20 & $<65$ \\
$4 \mathrm{H}-\mathrm{CC}$ & 31.40 & 1 & 0.20 & $<65$ \\
$5 \mathrm{H}-2,68-72$ & 33.58 & $1+$ & 0.30 & $<65$ \\
$5 \mathrm{H}-5,79-83$ & 38.19 & $1+$ & 0.30 & $<65$ \\
$6 \mathrm{H}-2,5-9$ & 42.45 & $2-$ & 0.38 & $<65$ \\
$6 \mathrm{H}-4,3-7$ & 45.43 & $2-$ & 0.38 & $<65$ \\
$7 \mathrm{H}-1,5-9$ & 50.45 & $2-$ & 0.38 & $<65$ \\
$7 \mathrm{H}-3,135-139$ & 53.57 & $2-$ & 0.38 & $<65$ \\
$7 \mathrm{H}-4,70-74$ & 54.32 & $2-$ & 0.38 & $<65$ \\
$8 \mathrm{H}-3,113-117$ & 64.03 & 2 & 0.45 & $<65$ \\
$8 \mathrm{H}-7,64-68$ & 69.54 & 2 & 0.45 & $<65$ \\
$9 \mathrm{H}-3,3-8$ & 72.43 & 2 & 0.45 & $<65$ \\
$9 \mathrm{H}-4,3-7$ & 73.93 & 2 & 0.45 & $<65$ \\
$9 \mathrm{H}-5,33-38$ & 75.73 & 2 & 0.45 & $<65$ \\
$9 \mathrm{H}-6,41-45$ & 77.31 & 2 & 0.45 & $<65$ \\
$10 \mathrm{H}-1,129-131$ & 80.19 & 2 & 0.45 & $<65$ \\
$10 \mathrm{H}-6,30-32$ & 86.70 & 2 & 0.45 & $<65$ \\
$12 \mathrm{X}-\mathrm{CC}, 6-8$ & 91.96 & 2 & 0.45 & $<65$ \\
$13 \mathrm{X}-2,52-56$ & 103.52 & 2 & 0.45 & $<65$ \\
$13 \mathrm{X}-3,4-8$ & 104.54 & 2 & 0.45 & $<65$ \\
\hline & & & & \\
\hline
\end{tabular}

upper igneous crust beneath a complete sediment seal (Davis, Mottl, Fisher, et al., 1992). Results from two holes, 857A and 857C, are reported here.

The pollen colors in both holes show a gradual increase in opacity (Tables 8, 9; Fig. 2). The pollen color in Hole 857A is consistent with low-temperature heating. Hole $857 \mathrm{C}$, the deepest hole investigated, shows a gradual increase in thermal alteration. The fragmented pine pollen grains are brown-black and show no clear structure down to 411.14 mbsf, approximately $80 \mathrm{~m}$ above the uppermost sill (Sample 139-857C-48R-2, 94-96 cm). Below this depth only black carbonized fragments are present and all shaped palynomorphs are absent.

The vitrinite reflectance thermal maturity profiles for Site 857 are shown in Figure 6 and Table 10. Hole 857A shows a very shallow, sublinear increase in thermal maturity over $100.84 \mathrm{mbsf}$. The organic matter, which is characterized as derived from terrestrial higher plants, is present as trace to low abundances of fine-dispersed particles. SFC observations indicate a moderate abundance of fluorescing liptinitic hydrogen-rich plant and algal remains, which form a mixed assemblage including megaspores, plant cuticles, dinoflagellate cysts, algae, trilete spores, and pollen grains. There is clearly a range of fluorescence colors and intensities from mid-orange to dark-orange spores, with megaspores showing the lowest fluorescence intensities (i.e., lower hydrogen content), and dinoflagellate cysts fluorescing an intense yellow/yellow-orange. SFC observations are consistent with the $\mathrm{VR}_{\mathrm{o}}$ measurements, which increase from $0.26 \% \mathrm{VR}_{\mathrm{o}}$ at $3.7 \mathrm{mbsf}$ $(139-857 \mathrm{~A}-1 \mathrm{H}-2,30-34 \mathrm{~cm})$ to $0.45 \% \mathrm{VR}_{\mathrm{o}}$ at $104.54 \mathrm{mbsf}(139-$ $857 \mathrm{~A}-13 \mathrm{X}-3,4-8 \mathrm{~cm})$. In terms of hydrocarbon generation, this trend is indicative of an increase from highly immature sediments to those approaching marginal maturity and temperatures $<50^{\circ} \mathrm{C}$ (Hunt, 1979).

The section analyzed from Hole $857 \mathrm{C}$ spans nearly $410 \mathrm{~m}$ in depth. The thermal maturity profile generated from vitrinite reflectance determinations (Fig. 6; Table 9) indicates that temperature histories may have affected sedimentary organic matter. The thermal maturity determinations from 2.75 mbsf (139-857C-1H-2, 125-129 $\mathrm{cm})$ to 115.5 mbsf $(139-857 \mathrm{C}-9 \mathrm{R}-1,100-102 \mathrm{~cm})$ does not agree closely with TAI date from the same interval. This may be due to the presence of indistinguishable low-level, reworked vitrinite clasts, which have artificially raised the thermal maturity determinations. The presence of reworked clasts is confirmed by fluorescence observations over this interval. Greater confidence should therefore be placed in the TAI data for this interval. The thermal maturity profile from 133.92 mbsf (139-857C-11R-1, 12-14 cm) down to $411 \mathrm{mbsf}$
Table 9. TAI of Hole 857C.

\begin{tabular}{|c|c|c|c|c|}
\hline $\begin{array}{l}\text { Core, section, } \\
\text { interval }(\mathrm{cm})\end{array}$ & $\begin{array}{l}\text { Depth } \\
\text { (mbst) }\end{array}$ & TAI & $\begin{array}{c}R_{0} \\
\text { equivalent }\end{array}$ & $\begin{array}{l}\text { Paleotemperature } \\
\left({ }^{\circ} \mathrm{C}\right) \text { inferred }\end{array}$ \\
\hline \multicolumn{5}{|l|}{$139-857 \mathrm{C}$ - } \\
\hline $1 \mathrm{R}-2,125-129$ & 2.75 & $1+$ & 0.30 & $<65$ \\
\hline $2 \mathrm{R}-1,6-11$ & 56.56 & $1+$ & 0.30 & $<65$ \\
\hline $2 \mathrm{R}-2,50-53$ & 58.50 & $1+$ & 0.30 & $<65$ \\
\hline $6 R-C C, 3-5$ & 89.38 & $2-$ & 0.38 & $<65$ \\
\hline $9 \mathrm{R}-1,100-102$ & 115.50 & $2-$ & 0.38 & $<65$ \\
\hline $10 \mathrm{R}-1,3-5$ & 124.13 & $2-$ & 0.38 & $<65$ \\
\hline $11 \mathrm{R}-1,12-14$ & 133.92 & $2-$ & 0.38 & $<65$ \\
\hline $12 \mathrm{R}-1,100-103$ & 144.50 & $2-$ & 0.38 & $<65$ \\
\hline $12 \mathrm{R}-2,63-66$ & 145.63 & $2+$ & 0.61 & $65-96$ \\
\hline $14 \mathrm{R}-2,61-65$ & 164.91 & $2+$ & 0.61 & $65-96$ \\
\hline $17 R-3,31-35$ & 195.21 & $2+$ & 0.61 & $65-96$ \\
\hline $18 \mathrm{R}-1,92-96$ & 202.52 & $3-$ & 0.78 & $65-96$ \\
\hline $21 R-3,83-86$ & 234.43 & $3-$ & 0.78 & $65-96$ \\
\hline $22 \mathrm{R}-1,95-98$ & 241.25 & $3-$ & 0.78 & $65-96$ \\
\hline $24 \mathrm{R}-1,49-53$ & 259.69 & $2+$ & 0.61 & $65-96$ \\
\hline $25 \mathrm{R}-1,43-45$ & 269.23 & $2+$ & 0.38 & $65-96$ \\
\hline $28 \mathrm{R}-1,34-36$ & 294.14 & $3-$ & 0.78 & $65-96$ \\
\hline $28 \mathrm{R}-2,16-18$ & 295.46 & 3 & 0.98 & $96-120$ \\
\hline $30 R-2,60-63$ & 315.20 & 3 & 0.98 & $96-120$ \\
\hline $34 \mathrm{R}-3,64-66$ & 340.14 & 4 & 1.71 & $120-200$ \\
\hline $40 R-1,21-24$ & 365.61 & $?$ & $?$ & ? \\
\hline $41 R-1,62-66$ & 375.52 & $?$ & ? & ? \\
\hline $43 R-2,23-26$ & 386.43 & ? & ? & ? \\
\hline $44 \mathrm{R}-2,105-109$ & 393.25 & ? & ? & ? \\
\hline $48 \mathrm{R}-2,94-96$ & 411.14 & 4 & 2.58 & $120-200$ \\
\hline $49 \mathrm{R}-3,8-11$ & 416.78 & $>4(?)$ & $>2.58(?)$ & $>200(?)$ \\
\hline $55 \mathrm{R}-1,8-10$ & 442.08 & $>4(?)$ & $>2.58(?)$ & $>200(?)$ \\
\hline
\end{tabular}

Table 10. Vitrinite reflectance and spore fluorescence color for whole sediment samples from Holes $857 \mathrm{~A}$ and $857 \mathrm{C}$.

\begin{tabular}{|c|c|c|c|c|c|}
\hline $\begin{array}{l}\text { Core, section. } \\
\text { interval }(\mathrm{cm})\end{array}$ & $\begin{array}{l}\text { Depth } \\
\text { (mbsf) }\end{array}$ & $\begin{array}{l}\text { Vitrinite } \\
\text { reflectance } \\
\left(\% \mathrm{VR}_{\mathrm{o}}\right)^{\mathrm{a}}\end{array}$ & $\begin{array}{c}\text { Number of } \\
\text { readings }\end{array}$ & $\begin{array}{l}\text { Standard } \\
\text { deviation }\end{array}$ & $\begin{array}{l}\text { Spore fluorescence } \\
\text { color (SFC) }\end{array}$ \\
\hline \multicolumn{6}{|l|}{ 139-857A- } \\
\hline $1 \mathrm{H}-2,30-34$ & 3.7 & 0.26 & 3 & 0.10 & green-yellow \\
\hline $4 \mathrm{H}-5,94-98$ & 28.84 & 0.38 & 10 & 0.04 & green-yellow \\
\hline $5 \mathrm{H}-5,79-83$ & 38.19 & 0.31 & 5 & 0.05 & green-yellow/yellow \\
\hline $6 \mathrm{H}-4,3-7$ & 45.43 & 0.37 & 5 & 0.09 & yellow \\
\hline $7 \mathrm{H}-3,135-139$ & 53.57 & 0.40 & 7 & 0.04 & yellow/yellow-orange \\
\hline $8 \mathrm{H}-7,64-68$ & 69.54 & 0.40 & 7 & 0.02 & yellow/yellow-orange \\
\hline $10 \mathrm{H}-1,129-131$ & 80.19 & 0.42 & 7 & 0.05 & yellow/yellow-orange \\
\hline $13 \mathrm{X}-3,4-8$ & 104.54 & 0.45 & 7 & 0.05 & yellow-orange \\
\hline \multicolumn{6}{|l|}{$139-857 \mathrm{C}$ - } \\
\hline 1R-2, 125-129 & 2.75 & 0.54 & 8 & 0.06 & yellow/yellow-orange \\
\hline $2 \mathrm{R}-2,50-53$ & 58.5 & 0.61 & 6 & 0.12 & light orange/mid-orange \\
\hline $9 \mathrm{R}-1,100-102$ & 115.5 & 0.63 & 11 & 0.08 & yellow-orange \\
\hline $11 \mathrm{R}-1.12-14$ & 133.92 & 0.47 & 10 & 0.07 & yellow-orange \\
\hline $12 \mathrm{R}-1,100-103$ & 144.50 & 0.60 & 8 & 0.07 & light orange/mid-orange \\
\hline $14 \mathrm{R}-2,61-65$ & 164.91 & 0.91 & 7 & 0.01 & mid-orange/dark orange \\
\hline $17 \mathrm{R}-3,31-35$ & 195.21 & 0.67 & 16 & 0.14 & mid-orange \\
\hline $21 \mathrm{R}-3,83-86$ & 234.43 & 0.72 & 15 & 0.08 & mid-orange \\
\hline $24 \mathrm{R}-1,49-53$ & 254.69 & 0.76 & 22 & 0.10 & light orange/mid-orange \\
\hline $25 \mathrm{R}-1,43-45$ & 269.23 & 0.95 & 18 & 0.08 & dark orange/red \\
\hline $28 \mathrm{R}-2,16-18$ & 295.46 & 1.10 & 13 & 0.16 & dark red/brown \\
\hline $30 \mathrm{R}-2,60-63$ & 315.20 & 1.13 & 17 & 0.15 & dark red/brown \\
\hline $40 \mathrm{R}-1,21-24$ & 365.61 & 1.46 & 9 & 0.05 & dark brown \\
\hline $43 R-2,23-26$ & 386.43 & 2.03 & 14 & 0.12 & none \\
\hline $48 \mathrm{R}-2,94-96$ & 411.14 & 2.48 & 14 & 0.19 & none \\
\hline
\end{tabular}

${ }^{\mathrm{a}}$ Mean vitrinite reflectance percent in oil $\left(\mathrm{n}_{\mathrm{e}} 1.518\right.$ at $\left.23^{\circ} \mathrm{C}\right)$.

(139-857C-48R-2, 94-96 cm) shows a generally increasing trend and agrees with TAI and SFC data if we neglect the "abnormally" high measurement $0.91 \% \mathrm{VR}_{\mathrm{o}}$ at $164.91 \mathrm{mbsf}$ (139-857C-14R-2, 61-65 $\mathrm{cm}$ ); the increasing maturity gradient from $365.61 \mathrm{mbsf}$ down to the base of the analyzed section is evident, compared to the gradient above this depth. Coincidentally, the profile of chlorinity of pore water between about 140 and $200 \mathrm{mbsf}$ has a similar trend, increasing to a maximum $574.4 \mathrm{mmol} / \mathrm{kg}$ at $145.05 \mathrm{mbsf}$, decreasing to 560 $\mathrm{mmol} / \mathrm{kg}$ at $203.18 \mathrm{mbsf}$, and then continuously increasing to 589.9 $\mathrm{mmol} / \mathrm{kg}$ at $415.13 \mathrm{mbsf}$ (Davis, Mottl, Fisher, et al., 1992). The "anomalous" high measurement/content of $\% \mathrm{VR}_{\mathrm{o}}$ /chlorinity around $145 / 165$ mbsf suggests that there may be thin sills intruded into sediments near this depth close to, but not actually intersecting Hole 857C (no sills were reported around 145-165 mbsf in the hole). Lateral hydrothermal discharge from the sills, or from some unknown 


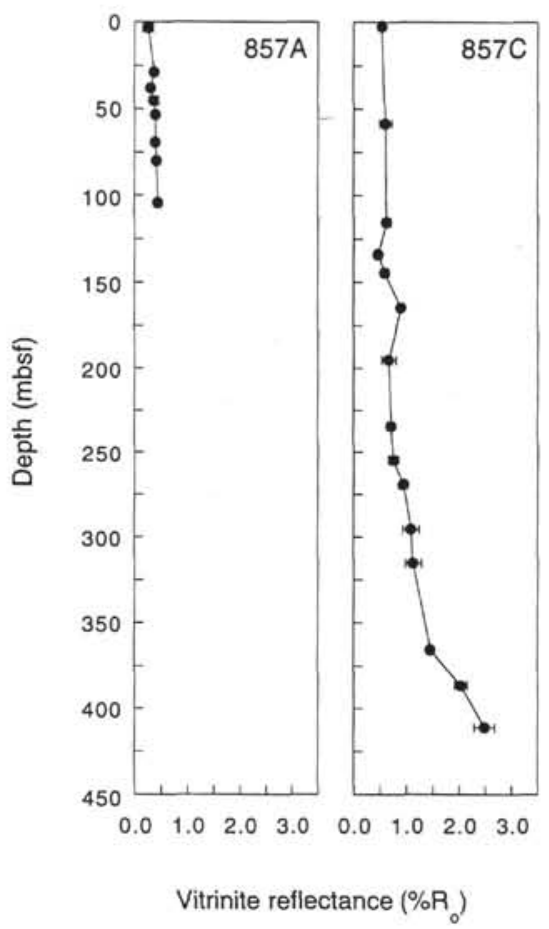

Figure 6. Vitrinite reflectance maturation profiles for Holes 857A and 857C.

events, may be responsible for the "abnormally" high \% VR/content of chlorinity around this depth interval. The $\% \mathrm{VR}_{\mathrm{o}}$ and TAI from the interval below 315.20 mbsf (139-857C-30R-2, 60-63 cm) tell the same story of an increasing maturity gradient that is in this case clearly related to the proximity of shallow mafic intrusive rocks at 471.10 mbsf (Davis, Mottl, Fisher, et al., 1992).

\section{Site 858}

Holes at this site were drilled directly into, and also adjacent to, a hydrothermal vent field. Analysis of Holes 858A, B, C, and D reveals sharp increases in thermal alteration, particularly at Holes $858 \mathrm{~B}$ and $858 \mathrm{C}$ (Tables 11, 12; Fig. 2). TAI values for Hole 858A exhibit a lesser degree of thermal alteration than those for the other three holes because the hole is near a hydrothermal discharge zone while the other three holes are within the discharge zone (Davis, Mottl, Fisher, et al., 1992). Altered pollen grains in Hole 858A show increased opacity with depth, but with a sharp increase in the TAI from a value of 2 at 20.24 mbsf (139-858A-3H-6, 107-111 cm) to 3+ at $33.32 \mathrm{mbsf}$ (139-858A-5H-2, 92-97 cm). Below this depth, the TAI fluctuates slightly but generally increases to a maximum TAI of $>4$ by 255.60 mbsf (139-858A-30X-CC). Since no sills at Hole 858A were recorded above $255.6 \mathrm{mbsf}$, the lateral fluid flow carrying heat from the hydrothermal vent field must be responsible for the sharp increase in TAI. It is not clear why in some of the shallow samples (for example, Samples 139-858A-7H-1, 69-72 cm and 139-858A-7H-CC), the sediments seem to be devoid of palynomorphs. In samples below $198.14 \mathrm{mbsf}$ (139-858A-24X-1,54-56 cm), no palynomorphs but black carbonized fragments were recovered. This is interpreted to be the result of exposure to high temperatures which "overcooked" the palynomorphs and carbonized/graphitized them. In the other three holes $(858 \mathrm{~B}, 858 \mathrm{C}$, and $858 \mathrm{D})$ a similar scenario is evident particularly at the sections below 18.4 mbsf (139-858B-3H-CC), 11.68 mbsf (138-858C-2H-6, 68-70 $\mathrm{cm}$ ), and $27.62 \mathrm{mbsf}(139-858 \mathrm{D}-4 \mathrm{H}-7,8-12 \mathrm{~cm})$, respectively, indicating that the temperatures within these sections were so high that the palynomorphs were destroyed. The thermal regime above these depths in Holes 858B, 858C, and 858D is conductive (Davis, Mottl, Fisher, et al., 1992), and the sections contain pine pollen grains of light yellow
Table 11. TAI of Hole 858A.

\begin{tabular}{lcccc}
\hline $\begin{array}{c}\text { Core, section, } \\
\text { interval }(\mathrm{cm})\end{array}$ & $\begin{array}{c}\text { Depth } \\
\text { (mbsf) }\end{array}$ & TAI & $\begin{array}{c}\mathrm{R}_{\mathrm{o}} \\
\text { equivalent }\end{array}$ & $\begin{array}{c}\text { Paleotemperature } \\
\left({ }^{\circ} \mathrm{C}\right) \text { inferred }\end{array}$ \\
\hline 139-858A- & & & & \\
1H-1,93-95 & 0.93 & $1+$ & 0.30 & $<65$ \\
$1 \mathrm{H}-\mathrm{CC}$ & 2.40 & $1+$ & 0.30 & $<65$ \\
$2 \mathrm{H}-1,42-44$ & 2.82 & $1+$ & 0.30 & $<65$ \\
$2 \mathrm{H}-5,6-10$ & 8.46 & $2-$ & 0.38 & $<65$ \\
$2 \mathrm{H}-\mathrm{CC}$ & 11.9 & $2-$ & 0.38 & $<65$ \\
$3 \mathrm{H}-4,68-72$ & 16.85 & 2 & 0.38 & $<65$ \\
$3 \mathrm{H}-6,107-111$ & 20.24 & 2 & 0.38 & $<65$ \\
$4 \mathrm{H}-\mathrm{CC}$ & 30.90 & $2+$ & 0.61 & $65-96$ \\
$5 \mathrm{H}-2,92-97$ & 33.32 & $3+$ & 1.16 & $96-120$ \\
$6 \mathrm{H}-3,105-107$ & 44.45 & $3+$ & 1.16 & $96-120$ \\
$7 \mathrm{H}-1,69-72$ & 50.59 & $?$ & $?$ & $?$ \\
$7 \mathrm{H}-3,72-75$ & 53.62 & 3 & 0.98 & $96-120$ \\
$7 \mathrm{H}-\mathrm{CC}$ & 58.90 & $?$ & $?$ & $?$ \\
$8 \mathrm{H}-3,70-72$ & 62.48 & 3 & 0.98 & $96-120$ \\
$9 \mathrm{X}-4,57-61$ & 67.57 & $3+$ & 1.16 & $96-120$ \\
$9 \mathrm{X}-\mathrm{CC}$ & 71.90 & $3-$ & 0.78 & $65-96$ \\
$11 \mathrm{XCC}, 37-39$ & 73.87 & 3 & 0.98 & $96-120$ \\
$12 \mathrm{X}-1,10-12$ & 81.70 & 3 & 0.98 & $96-120$ \\
$18 \mathrm{X}-\mathrm{CC}$ & 149.30 & $?$ & $?$ & $?$ \\
$19 \mathrm{X}-1,32-34$ & 149.62 & $3+$ & 1.16 & $96-120$ \\
$20 \mathrm{X}-3,106-109$ & 163.06 & $?$ & $?$ & $?$ \\
$21 \mathrm{X}-3,70-72$ & 172.10 & $?$ & $?$ & $?$ \\
$24 \mathrm{X}-1,54-56$ & 198.14 & $4-$ & 2.58 & $120-200$ \\
$30 \mathrm{X}-\mathrm{CC}$ & 256.60 & $>4(?)$ & $>2.58(?)$ & $>200(?)$ \\
$31 \mathrm{X}-2,31-33$ & 266.41 & $>4(?)$ & $>2.58(?)$ & $>200(?)$ \\
$31 \mathrm{X}-\mathrm{CC}$ & 266.45 & $>4(?)$ & $>2.58(?)$ & $>200(?)$ \\
$32 \mathrm{X}-\mathrm{CC}$ & 281.70 & $>4(?)$ & $>2.58(?)$ & $>200(?)$ \\
$34 \mathrm{X}-\mathrm{CC}$ & 301.4 & $>4(?)$ & $>2.58(?)$ & $>200(?)$ \\
\hline
\end{tabular}

Table 12. TAI of Holes 858B, 858C, and 858D.

\begin{tabular}{|c|c|c|c|c|}
\hline $\begin{array}{l}\text { Core, section, } \\
\text { interval }(\mathrm{cm})\end{array}$ & $\begin{array}{l}\text { Depth } \\
\text { (mbsf) }\end{array}$ & TAI & $\begin{array}{c}\mathrm{R}_{\mathrm{o}} \\
\text { equivalent }\end{array}$ & $\begin{array}{c}\text { Paleotemperature } \\
\left({ }^{\circ} \mathrm{C}\right) \text { inferred }\end{array}$ \\
\hline \multicolumn{5}{|l|}{$139-858 \mathrm{~B}-$} \\
\hline $1 \mathrm{H}-1,84-88$ & 0.84 & $1+$ & 0.30 & $<65$ \\
\hline $\mathrm{IH}-3,58-62$ & 3.58 & $1+$ & 0.30 & $<65$ \\
\hline $\mathrm{IH}-4,60-64$ & 5.10 & 2 & 0.45 & $<65$ \\
\hline IH $-5,45-47$ & 6.45 & $2+$ & 0.61 & $65-96$ \\
\hline $\mathrm{IH}-\mathrm{CC}$ & 7.20 & $2+$ & 0.61 & $65-96$ \\
\hline $2 \mathrm{H}-4,124-126$ & 12.94 & $?$ & ? & ? \\
\hline $2 \mathrm{H}-7,12-14$ & 16.32 & $?$ & $?$ & \\
\hline $3 \mathrm{H}-\mathrm{CC}$ & 18.4 & $2+$ & 0.61 & $65-96$ \\
\hline $4 \mathrm{H}-\mathrm{CC}$ & 23.9 & $>4(?)$ & $>2.58(?)$ & $>200(?)$ \\
\hline \multicolumn{5}{|l|}{$139-858 \mathrm{C}-$} \\
\hline $1 \mathrm{H}-3,25-29$ & 3.25 & $1+$ & 0.30 & $<65$ \\
\hline $2 \mathrm{H}-2,88-90$ & 5.88 & $2-$ & 0.38 & $<65$ \\
\hline $2 \mathrm{H}-4,44-46$ & 8.44 & 2 & 0.45 & $<65$ \\
\hline $2 \mathrm{H}-5,39-41$ & 9.89 & 2 & 0.45 & $<65$ \\
\hline $2 \mathrm{H}-6,68-70$ & 11.68 & $2+$ & 0.61 & $65-96$ \\
\hline $7 \mathrm{H}-1,25-28$ & 41.75 & $>4(?)$ & $>2.58(?)$ & $>200(?)$ \\
\hline $7 \mathrm{H}-\mathrm{CC}$ & 46.50 & $>4(?)$ & $>2.58(?)$ & $>200(?)$ \\
\hline $14 \mathrm{X}-\mathrm{CC}$ & 93.10 & $>4(?)$ & $>2.58(?)$ & $>200(?)$ \\
\hline \multicolumn{5}{|l|}{ 139-858D- } \\
\hline $1 \mathrm{H}-1,77-81$ & 0.77 & $1+$ & 0.30 & $<65$ \\
\hline 1H-2, $84-85$ & 2.34 & $1+$ & 0.30 & $<65$ \\
\hline $1 \mathrm{H}-5,68-72$ & 6.68 & $1+$ & 0.30 & $<65$ \\
\hline $2 \mathrm{H}-4,114-116$ & 14.94 & 2 & 0.45 & $<65$ \\
\hline $2 \mathrm{H}-\mathrm{CC}$ & 18.80 & $1+$ & 0.30 & $<65$ \\
\hline $3 \mathrm{P}-1,34-36$ & 19.14 & $?$ & $?$ & $?$ \\
\hline $4 \mathrm{H}-3,44-48$ & 21.98 & $?$ & $?$ & $?$ \\
\hline $4 \mathrm{H}-4,23-27$ & 23.28 & $2+$ & 0.61 & $65-96$ \\
\hline $4 \mathrm{H}-7,8-12$ & 27.62 & 2 & 0.45 & $<65$ \\
\hline $6 \mathrm{X}-1,75-77$ & 29.55 & $>4(?)$ & $2.58(?)$ & $>200(?)$ \\
\hline
\end{tabular}

to dark yellow colors with the TAI ranging from a value of $1+$ at a depth directly below sea bottom to $2+$ above these depths.

The thermal maturity gradients for Site 858 as derived from vitrinite reflectance data (Table 13) are shown in Figure 7. A rapid temperature increase in Hole $858 \mathrm{~A}$ is broken by an abrupt divergence from the main trend. A significant increase in $\mathrm{VR}_{\mathrm{o}}$ is recorded at $44.45 \mathrm{mbsf}$ (139-858A-6H-3, 105-107 cm), where $\mathrm{VR}_{\mathrm{o}}$ increases to early gas condensate maturity, $1.24 \%$ from a mature $0.53 \% \mathrm{VR}_{\mathrm{o}}$ at $16.85 \mathrm{mbsf}$ (139-858A-3H-4, 68-72 cm). Dark black bitumen staining around organic clasts is interpreted to be the result of exposure to high temperatures with the in-situ generation of hydrocarbons between 


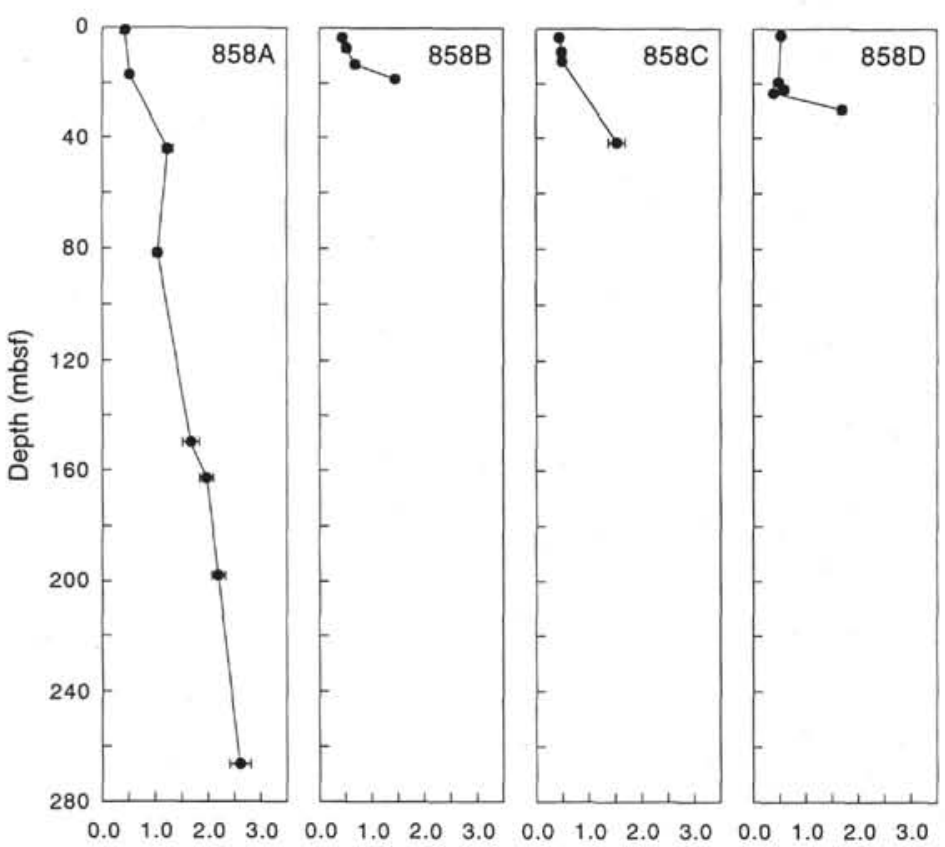

Vitrinite reflectance $\left(\% R_{0}\right)$

44.45 and 149.62 mbsf (139-858A-19X-1, 32-34 cm). A moderately heavy dark-brown/black matrix staining is interpreted as evidence of the migration of mature hydrocarbons through the sediments in this interval. $\mathrm{VR}_{\mathrm{o}}$ values drop to $1.05 \%$ in the middle of this interval $(81.7$ mbsf) but then gradually increase to dry gas maturity, $2.61 \% \mathrm{VR}_{\mathrm{o}}$, by $266.45 \mathrm{mbsf}(139-858 \mathrm{~A}-31 \mathrm{X}-2,31-33 \mathrm{~cm})$ where graphitized fragments appear. These are probably the carbonized end products of a phase of severe heating experienced by these sediments. There is also an increased degree of brown-red Fe-oxide staining indicating that oxidizing fluids may have circulated through these sediments. The sharp perturbation in the maturity profile at $44.45 \mathrm{mbsf}$ is attributed to a circulating pulse of hot fluids.

Three other holes analyzed (858B, 858C, and 858D) show similar abrupt increases in thermal maturity but over shallower depth ranges. Sediments in Hole 858B show an increase from marginal maturity $\left(0.45 \% \mathrm{VR}_{\mathrm{o}}\right)$ at $3.58 \mathrm{mbsf}(139-858 \mathrm{~B}-1 \mathrm{H}-3,58-62 \mathrm{~cm})$ to end of oil window-beginning of gas condensate maturity $\left(1.45 \% \mathrm{VR}_{\mathrm{o}}\right)$ by 18.41 mbsf (139-858B-3HCC). In Hole $858 \mathrm{C}$ the thermal maturity range is consistent with Hole $858 \mathrm{~B}$ but occurs over a broader depth interval (3.25 - $83.8 \mathrm{mbsf}$ ) (Fig. 7; Table 12). Hole 858D shows an increase in $\mathrm{VR}_{\mathrm{o}}$ from a mature $0.53 \% \mathrm{VR}_{\mathrm{o}}$ at $2.34 \mathrm{mbsf}(139-858 \mathrm{D}$ $1 \mathrm{H}-2,84-88 \mathrm{~cm}$ ) to gas condensate maturity $1.68 \% \mathrm{VR}_{\mathrm{o}}$ at $29.55 \mathrm{mbsf}$ (139-858D-6X-1, 75-77 cm), although there are slight fluctuations in maturity between $19.41 \mathrm{mbsf}(139-858 \mathrm{D}-3 \mathrm{R}-1,34-36 \mathrm{~cm}$ ) and 23.27 mbsf (139-858D-4H-4, 75-77 cm). The anomalously low $\mathrm{VR}_{\mathrm{o}}$ reading of $0.39 \%(139-858 \mathrm{D}-4 \mathrm{H}-4,23-27 \mathrm{~cm})$ is based on a single measurement which may have been affected by polishing blemishes; therefore, more confidence is placed in the SFC, which indicates that the sediments are more mature and in the range of mature oil window at $\sim 0.75 \% \mathrm{VR}_{\mathrm{o}}$. However, some megaspores downhole show a dichotomy in fluorescence color and appear "scorched." The majority of the outer walls fluoresce mid-orange to red color, while a smaller proportion fluoresced yellow to light-orange. This phenomenon was observed in samples at depths of 12.94 mbsf (139-858B-2H-4, 124-126 $\mathrm{cm}$ ) and $21.98 \mathrm{mbsf}(139-858 \mathrm{D}-4 \mathrm{H}-3,44-48 \mathrm{~cm}$ ) in Holes 858B and $858 \mathrm{D}$, respectively. This may indicate that the sediments have been exposed to an extremely high temperature for a brief period of time. The short exposure time may have prohibited the total alteration of the spore wall. A chemical study may indicate the retention of longer
Figure 7. Vitrinite reflectance maturation profiles for Holes 858A, 858B, $858 \mathrm{C}$, and $858 \mathrm{D}$.

chained aliphatic compounds within the spore, which would enhance the fluorescence properties by dilution of the aromatic chromophores (Bertrand et al., 1986). Additional observations of inorganic constituents reveal an increase in pyrite, red-brown $\mathrm{Fe}$-oxide staining, and aluminosilicate with depth.

The rapid increases in thermal maturity at this site are consistent with fast heating, probably by active upflowing hydrothermal fluids with a minor influence of heating associated with contact metamorphism from intruding sills (Hole 858A).

\section{DISCUSSION OF ESTIMATES FOR EXPOSURE TEMPERATURES OF SEDIMENTS}

Precise determination of the depths of onset and cessation of the oil window and hydrocarbon generation zones are of paramount importance in hydrocarbon exploration. However, less attention has been paid to the estimation of the paleotemperature to which source rocks are exposed during the generation of oil and gas. Some temperature data have been provided by Cardott and Lambert (1985) and Hao and Mao (1989) (Table 13). However, none of these reports correlates TAI to the equivalent temperature $\left({ }^{\circ} \mathrm{C}\right)$. Hao and Mao (1989) based their estimates on data gathered from several oil fields in China and integrated the data with data from laboratory heating experiments on modern pollen grains. Organic geochemical measurements on some samples from this leg (Whelan et al., this volume) show that the measured paleotemperature of Section 139-855C-1R-2 (96.2 mbsf) is $33^{\circ} \mathrm{C}$; of Section $139-857 \mathrm{C}-6 \mathrm{R}-2$ ( $\left.88.3 \mathrm{mbsf}\right)$, about $60^{\circ} \mathrm{C}$; of Section 139-857C-41R-3 (378.6 mbsf), about $210^{\circ} \mathrm{C}$; and of Section 139$858 \mathrm{~B}-1 \mathrm{H}-4$ ( $5.97 \mathrm{mbsf}$ ), about $65^{\circ} \mathrm{C}$. Trapping temperature based on calculated carbon and oxygen isotope composition of pore fluid of Sample $139-858 \mathrm{C}-3 \mathrm{H}-1,145-150 \mathrm{~cm}$ is read as $103^{\circ} \mathrm{C}$ and $\sim 234^{\circ} \mathrm{C}$ in Sample 139-858C-3H-3, 22-24 cm (Goodfellow, this volume). The investigation on qualitative and quantitative secondary alteration of the pollen grains of Pinus silvestris, P. mugo and Picea glauca (Kedves et al., 1992) indicates that high-temperature exposure damages the sacci. Similarly, the pollen grains heated isothermally at $200^{\circ} \mathrm{C}$ at different residence times in the laboratory showed that time was an important factor; pollen grains heated for the longest times resulted in more highly damaged sacci. However, the experiment also 
Table 13. Vitrinite reflectance and spore fluorescence color for whole sediment samples from Holes 858A, 858B, 858C, and 858D.

\begin{tabular}{|c|c|c|c|c|c|}
\hline $\begin{array}{l}\text { Core, section, } \\
\text { interval }(\mathrm{cm})\end{array}$ & $\begin{array}{l}\text { Depth } \\
\text { (mbst) }\end{array}$ & $\begin{array}{l}\text { Vitrinite } \\
\text { reflectance } \\
\left(\% \mathrm{VR}_{\mathrm{o}}\right)^{\mathrm{a}}\end{array}$ & $\begin{array}{l}\text { Number of } \\
\text { readings }\end{array}$ & $\begin{array}{l}\text { Standard } \\
\text { deviation }\end{array}$ & $\begin{array}{l}\text { Spore fluorescence color } \\
\text { (SFC) }\end{array}$ \\
\hline \multicolumn{6}{|l|}{$139-858 \mathrm{~A}-$} \\
\hline $1 \mathrm{H}-1,93-95$ & 0.93 & 0.43 & 17 & 0.09 & yellow-crange/light orange \\
\hline $3 \mathrm{H}-4,68-72$ & 16.85 & 0.52 & 5 & 0.04 & yellow-orange/light orange \\
\hline $6 \mathrm{H}-3,105-107$ & 44.45 & 1.24 & 17 & 0.10 & none \\
\hline $12 X-1,10-12$ & 81.70 & 1.05 & 17 & 0.08 & none \\
\hline $19 X-1,32-34$ & 149.62 & 1.67 & 15 & 0.16 & none \\
\hline $20 X-3,106-109$ & 163.06 & 1.98 & 15 & 0.13 & none \\
\hline $24 X-1,54-56$ & 198.14 & 2.20 & 19 & 0.13 & none \\
\hline $31 X-2,31-33$ & 266.45 & 2.61 & 19 & 0.20 & none \\
\hline \multicolumn{6}{|l|}{ 139-858B- } \\
\hline $1 \mathrm{H}-3,58-62$ & 3.58 & 0.45 & 13 & 0.03 & yellow-orange \\
\hline $1 \mathrm{H}-\mathrm{CC}$ & 7.20 & 0.52 & 10 & 0.08 & dark orange \\
\hline $2 \mathrm{H}-4,124-126$ & 12.94 & 0.69 & 5 & 0.07 & dark orange \\
\hline $3 \mathrm{H}-\mathrm{CC}$ & 18.41 & 1.45 & 3 & 0.04 & none \\
\hline \multicolumn{6}{|l|}{$139-858 \mathrm{C}$ - } \\
\hline $1 \mathrm{H}-3,25-29$ & 3.25 & 0.45 & 9 & 0.06 & yellow-orange \\
\hline $2 \mathrm{H}-4,44 \quad 46$ & 8.44 & 0.49 & 9 & 0.07 & yellow/yellow-orange \\
\hline $2 \mathrm{H}-6,68-70$ & 11.68 & 0.50 & 5 & 0.05 & yellow-orange \\
\hline $7 \mathrm{H}-1,25-28$ & 41.75 & 1.54 & 12 & 0.16 & none \\
\hline $14 \mathrm{X}-\mathrm{CC}$ & 83.80 & 1.41 & 4 & 0.12 & none \\
\hline \multicolumn{6}{|l|}{ 139-858D- } \\
\hline $1 \mathrm{H}-2,84-88$ & 2.34 & 0.53 & 3 & 0.02 & light orange/mid-orange \\
\hline $3 \mathrm{R}-1,34-36$ & 19.14 & 0.48 & 5 & 0.09 & light orange \\
\hline $4 \mathrm{H}-3,44 \quad 48$ & 21.98 & 0.59 & 4 & 0.07 & light orange/dark orange \\
\hline $4 \mathrm{H}-4,23-27$ & 23.27 & 0.39 & 1 & 0.00 & dark orange \\
\hline $6 \mathrm{X}-1,75-77$ & 29.55 & 1.68 & 4 & 0.08 & none \\
\hline
\end{tabular}

${ }^{a}$ Mean vitrinite reflectance percent in oil $\left(\mathrm{n}_{\mathrm{e}} 1.518\right.$ at $\left.23^{\circ} \mathrm{C}\right)$.

demonstrates that for as long as the bisaccate pollen can be recognized, the exposure temperature could be as high as $200^{\circ} \mathrm{C}$. Therefore, we suggest that $200^{\circ} \mathrm{C}$ is the threshold temperature that palynomorphs can withstand and remain recognizable in transmitted light. Above $200^{\circ} \mathrm{C}$ the bisaccate pollen is carbonized or destroyed completely and only black carbonized fragments are encountered in the organic residues. We have tried to establish an ideal temperature series to correlate with the different degrees of thermal alteration based on data from Cardott and Lambert (1985) and Mao (in Hao and Mao et al., 1989) integrated with those new data gained from the geochemical study and other methods mentioned above (Table 13). At this stage, our conclusion is preliminary.

\section{CONCLUSIONS}

The most striking finding of this study is the dramatic increase in thermal maturity that occurs over extremely short depth intervals (20-450 m), especially at Sites 856,857 , and 858 . Comparison of TAI, VR $\mathrm{N}_{\mathrm{o}}$ and SFC data, in general, show good agreement, both internally and with other geochemical parameters (Whelan et al., this volume). These findings indicate that we can be confident that the sharp maturation jumps indicate real temperature differences. These rapid changes in maturity over small depth intervals indicate that vitrinite reacts and stabilizes rapidly to increased temperature even over short exposure times. Laboratory experiments, however, indicate that TAI is more time-dependent. The time-temperature relationship for the maturation of organic matter in this type of hydrothermal system is, therefore, open to re-evaluation. In such a hydrothermal field area the complexity of fluid flow, circulation, intrusion, slumping, and concomitant supply of new sediments make reconstruction of discrete events difficult. The TAI study combined with $\mathrm{VR}_{\mathrm{o}}$ and SFC work illustrates a multifaceted approach to the characterization of different thermal alteration gradients in the study area and may be used in conjunction with data from other fields to help characterize these systems more fully. Site 855 provides a regional background thermal gradient upon which the hydrothermal gradients in the other holes are superimposed. Strong maturation increases with depth at
Sites 856 and 858 ; we infer that they have experienced high temperature exposure. The maturation profiles for Site 856 (interpreted as an extinct hydrothermal vent field; Davis, Mottl, Fisher, et al., 1992) indicate that Hole $856 \mathrm{~B}$ was closer than Hole $856 \mathrm{~A}$ to the heat source(s). Site 857 also exhibits accelerated maturation with depth, superimposed upon this trend by a possibly lateral heat flow.

\section{ACKNOWLEDGMENTS}

The study was supported by the Ocean Drilling Program and U.S Scientific Advisory Committee (USSAC) grants for S. Mao and J. Whelan. Lab facilities at the Department of Geology, Florida State University were provided by grant from the National Science Foundation (NFS) grant 91-18480 to S.W. Wise. We thank J. Jansonius for his helpful suggestions to the TAI study. Thanks are also extended to D.R. Logan and D.L. Pearson from Phillips Petroleum Company for offering us the up-to-date version of their TAI "standard" and related data, and their constructive suggestions. The first author would like to extend her special thanks to S.W. Wise of the Department of Geology, Florida State University for his encouragement and recommendation to participate in Leg 139 of the Ocean Drilling Program. The second author would like to thank Jeff Seewald for useful discussions and Meghan Delaney for technical assistance. Additional financial support was provided by Department of Energy grant No. 113466.00 to J.K. Whelan. Woods Hole Oceanographic Contribution No. 8261.

\section{REFERENCES}

Alpern, B., 1970. Classification pétrographique des constituants organiques fossils des roches sédimentaires. Rev. Inst. Fr. Pet. Ann. Combust. Liq., 25:1233-1266.

Barker, C.E., 1991. Implications for organic maturation studies of evidence for a geologically rapid increase and stabilization of vitrinite reflectance

\footnotetext{
- Abbreviations for names of organizations and publications in ODP reference lists follow the style given in Chemical Abstracts Service Source Index (published by American Chemical Society).
} 
at peak temperature: Cerro Prieto Geothermal System, Mexico. AAPG Bull., 75:1852-1863.

Barker, C.E., Crysdale, B.L., and Pawlewicz, M.J., 1986. Relationship between vitrinite reflectance, metamorphic grade, and temperature in the Cerro Prieto, Salton Sea, and East Mesa geothermal systems, Salton Trough, United States and Mexico. In Mumpton, F.A., and Bodine, M.W., Jr. (Eds.), Studies in Diagenesis. U.S. Geol. Surv. Bull., 1578:83-95.

Bertrand, P., Pittion, J.L., and Bernaud, C., 1986. Fluorescence of sedimentary organic matter in relation to its chemical composition. In Leythaeuser, D., and Rüllkotter, J. (Eds.), Advances in Organic Geochemistry, 1985: Part I, Petroleum Geochemistry. Org. Geochem., 10:641-647.

Bostick, N.H., and Pawlewicz, M.J., 1984. Paleotemperatures based on vitrinite reflectance of shales and limestones in igneous dike aureoles in the Upper Cretaceous Pierre Shale, Walsenburg, Colorado. In Woodward, J., Meissner, F.F., and Clayton, J.L., (Eds.), Hydrocarbon Source Rocks of the Greater Rocky Mountain Region: Denver (ARCO Explor. Co.), 387392

Cardott, B.J., and Lambert, M.W., 1985. Thermal maturation by vitrinite reflectance of Woodford Shale, Anadarko Basin, Oklahoma. AAPG Bull. 69:1982-1992.

Davis, E.E., Mottl, M.J., Fisher, A.T., et al., 1992. Proc. ODP, Init. Repts., 139: College Station, TX (Ocean Drilling Program).

Hao, Y., and Mao, S., (Eds.), 1989. Text Book of Micropaleontology: Beijing (China Univ. Geosci. Press.).

Hunt, J.M., 1979. Petroleum Geochemistry and Geology: San Francisco (W.H. Freeman)

International Committee for Coal Petrology, 1963. International Handbook of Coal Petrography (2nd ed.): Paris (Cent. Nat. Rech. Sci.). [1st suppl. to 2nd edition, 1971; reprinted 1985. 2nd suppl. to 2nd ed., 1975.]
Jacob, H., 1961. Uber bituminöse Schiefer, Humose Tone, Brandschiefer und ähnliche Gesteine. Ein Beitrag zur Frage der Erdölgenesis aus kohlenpetrographischer Sicht. Erdoel Kohle, 14:2-11.

1967. Petrologie von asphaltitien und asphaltischen Pyrobitumina. Erdoel Kohle, 20:217-226.

Kedves, M., Hegedüs, A., and Olah, I., 1992. High temperature effect of some bisaccate Gymnosperm pollen grains. In Kedves, M. (Ed.), Plant Cell Biology and Development, 3:14-37.

Pearson, D.L., 1990. Pollen/Spore Color "Standard" (Ver. 2): Bartelsville (Phillips Petroleum Co., Geology Branch).

Stach, E., Mackowsky, M.-T., Teichmüller, M., Taylor, G.H., Chandra, D., and Teichmüller, R., 1982. Stach's Textbook of Coal Petrology (3rd ed.): Berlin (Gebrüeder Borntraeger).

Staplin, F.L., 1969. Sedimentary organic matter, organic metamorphism and oil and gas occurrence. Bull. Can. Pet. Geol., 17:47-66

Tissot, B.P., Pelet, R., and Ungerer, P., 1987. Thermal history of sedimentary basins, maturation indices and kinetics of oil and gas generation. AAPG Bull., 71:1445-1466.

Traverse, A., 1988. Paleopalynology: Boston (Unwyn Hyman).

Ujiié, Y, 1986. Contact metamorphic effect on parameters for kerogen maturation. Org. Geochem., 9:375-378.

Date of initial receipt: 23 February 1993

Date of acceptance: 15 October 1993

Ms 139SR-209 

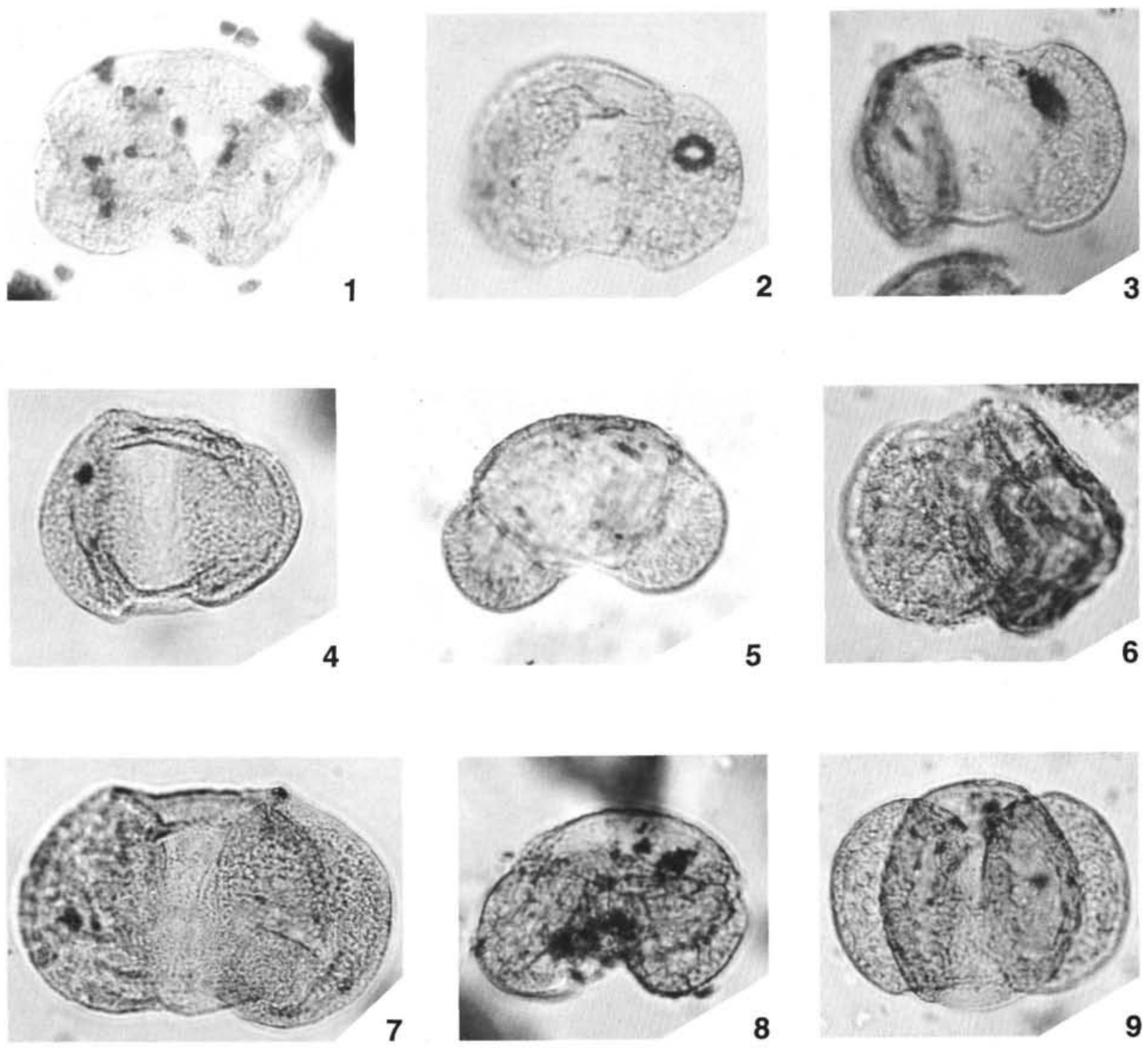

Plate 1. All photos are magnified $\times 600$. N.B. Pollen colors sometimes have deviations from the reported colors due to developing procedure or usage of a blue filter. 1. TAI = 1 (photo taken with blue filter). Sample 139-857A-4H-CC. 2-4. TAI = 1+. (2 and 3) Sample 139-857C-1R-2, 125-129 cm; (4) Sample 139-858A-2H-1, 42-44 cm. 5-8. TAI = 2. (5) Sample 139-857A-6H-4, 3-7 cm; (6) Sample 139-855A-6R-1, 91-94 cm; (7) Sample 139-858A-2H-5, 6-10 cm; (8) Sample 139-855C-8R-1, 35-39 cm. 9. TAI = 2, Sample 139-857A-8H-3, 113-117 cm. 

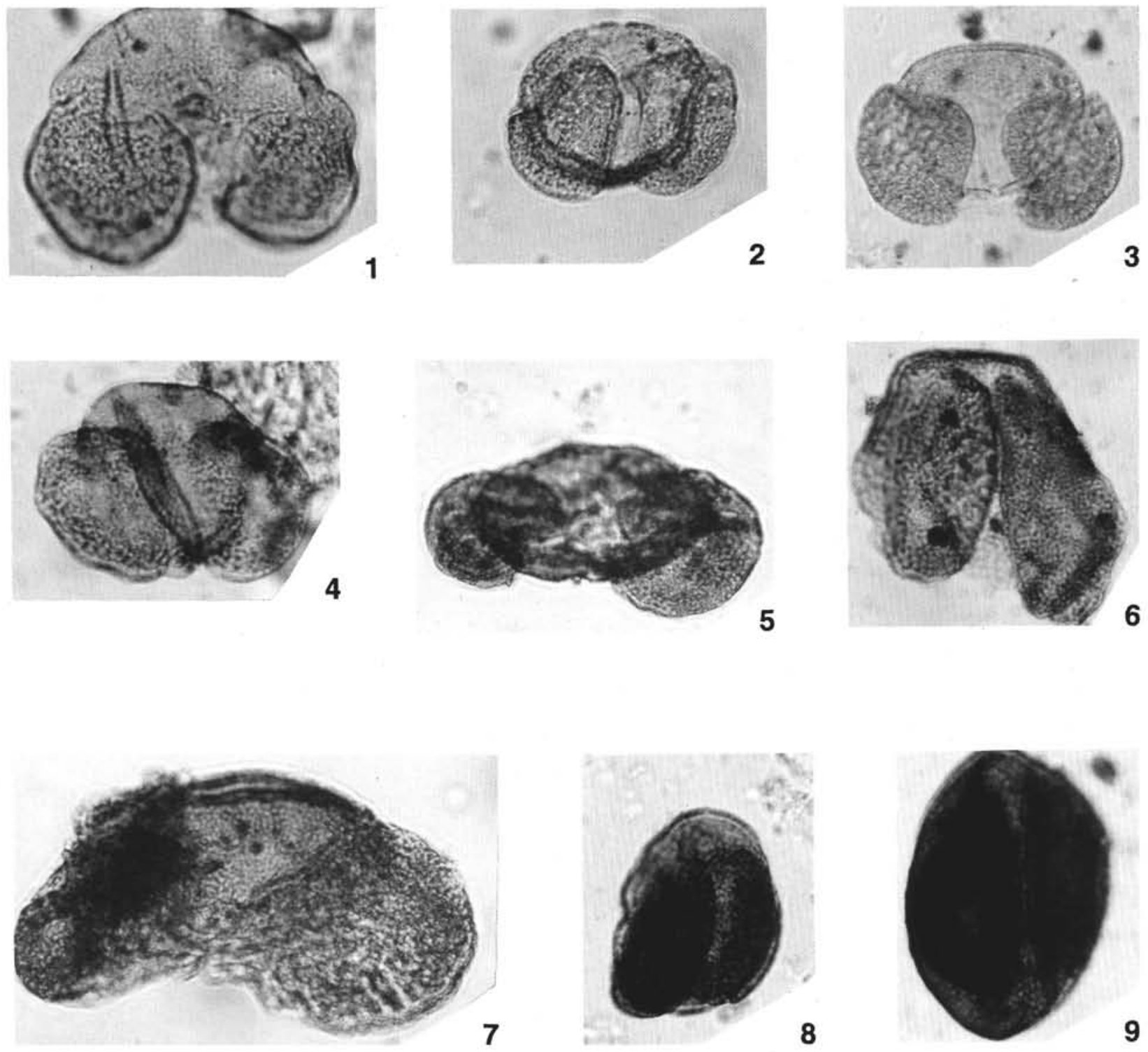

Plate 2. All photos are magnified $\times 600$. N.B. pollen colors sometimes have deviations from the reported colors due to developing procedure or usage of a blue filter. 1-3. TAI = 2. (1, 2) Sample 139-857A-10H-6, 30-32 cm; (3) Sample 139-856A-3H-5, 74-78 cm. 4, 5. TAI = 2+. (4) Sample 139-857C-25R-1, 43-45 cm; (5) Sample 139-857C-12R-2, 63-66 cm. 6-8. TAI = 3-. (6) Sample 139-857C-28R-1, 34-36 cm; (7) Sample 139-857C-21R-3, 83-85 cm; (8) Sample 139-857C-22R-1, 95-98 cm. 9. TAI = 3. Sample 139-858A-8H-3, 70-73 cm. 

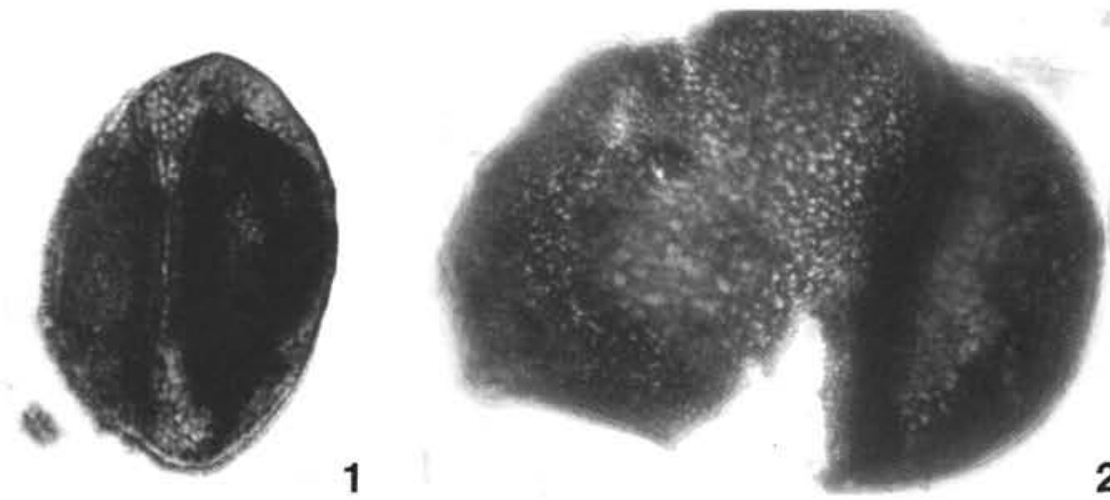

2

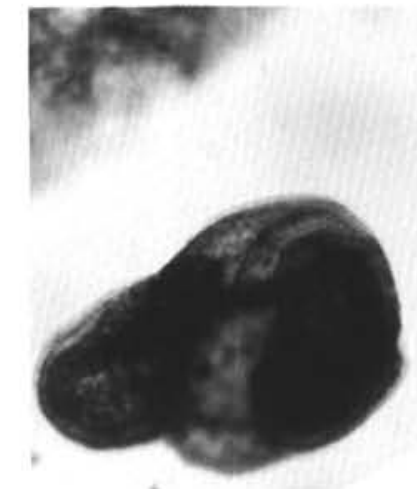

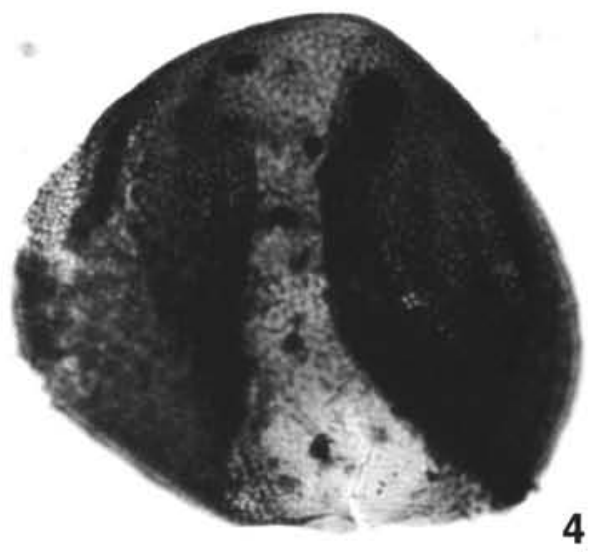
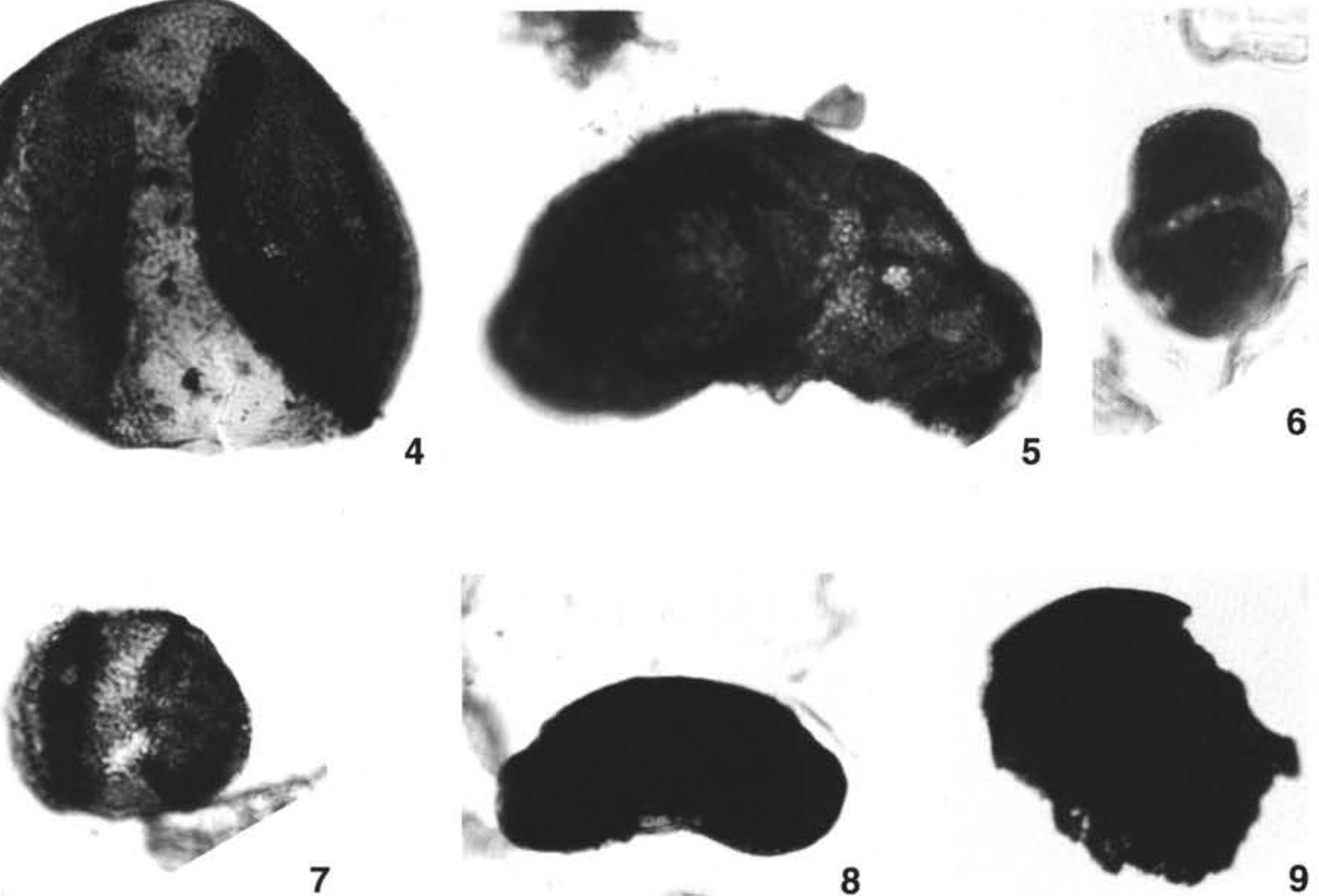

Plate 3. All photos are magnified $\times 600$. N.B. Pollen colors sometimes have deviations from the reported colors due to developing procedure or usage of a blue filter. 1-4. TAI = 3. (1) Sample 139-858A-8H-3, 70-73 cm; (2) (photo taken with blue filter) Sample 139-858A-11X-CC, 37-39 cm; (3) Sample 139-858A-12X-1, 10-12 cm; (4) Sample 139-856A-5H-3, 38-42 cm. 5. TAI = 3+, Sample 139-858A-9X-4, 57-61 cm. 6, 7. TAI = 4-. (6) (photo taken with blue filter) Sample 139-856B-5H-4, 124-128; (7) Sample 139-858A-24X-1, 54-56 cm. 8, 9. TAI =4, (8) Sample 139-856A-9H-7, $32-36 \mathrm{~cm}$; (9) Sample 139-857C-48R-2, 94-96 cm. 